\title{
EXHIBTION OF
}

6512

AMERICAN ART

E965

NMAA

SUITH80HIIS

utranites 

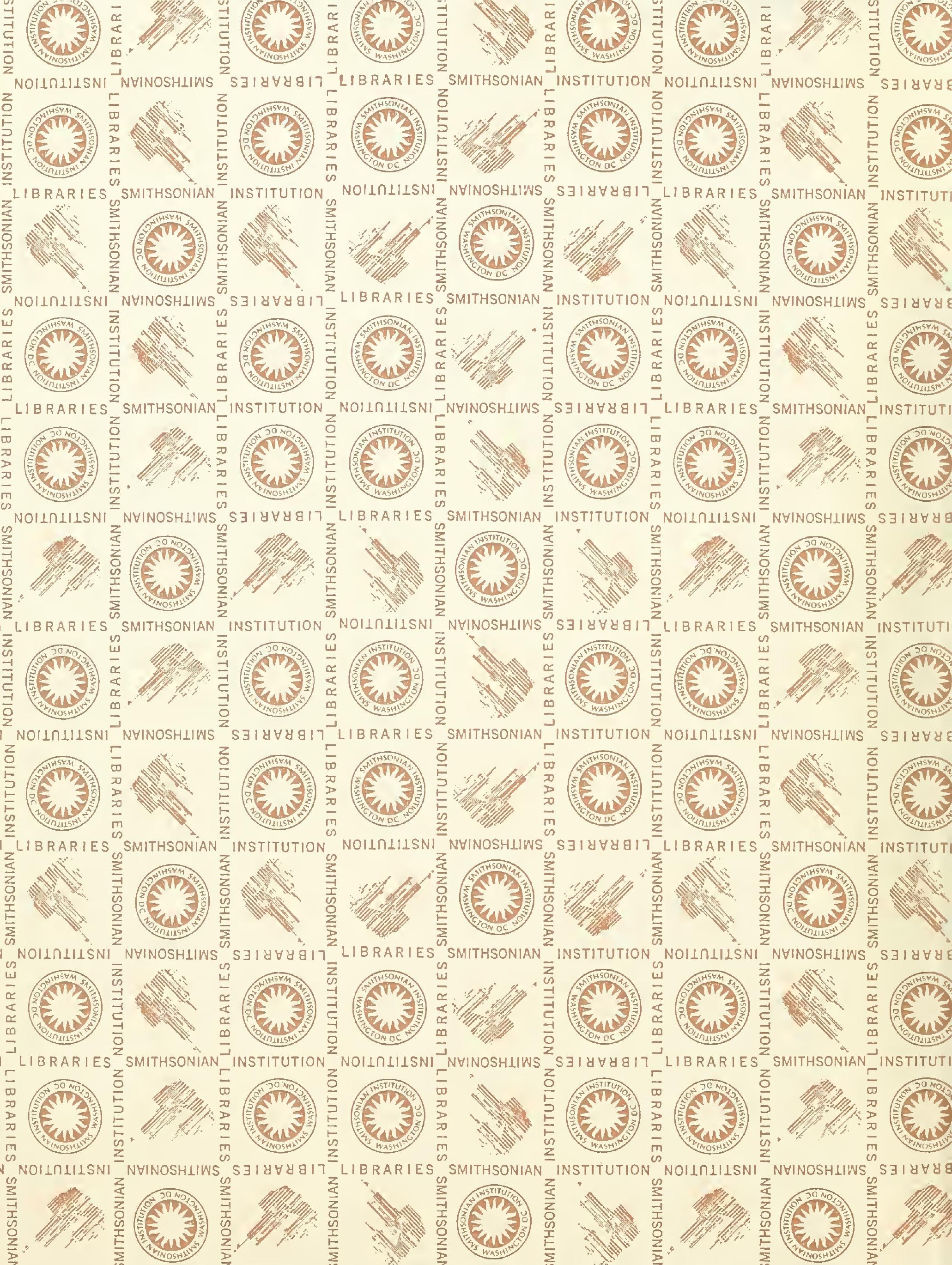

NO1101115N1
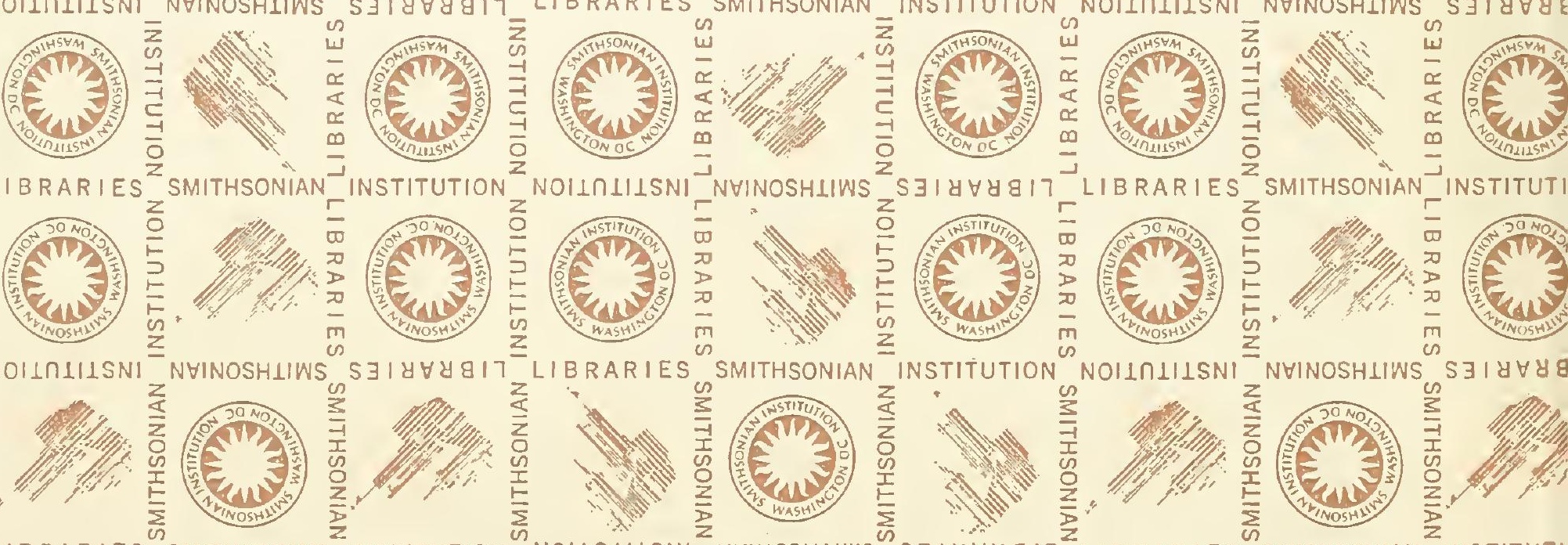


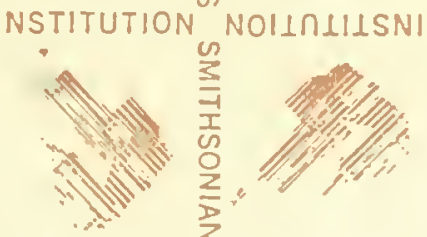

(2)
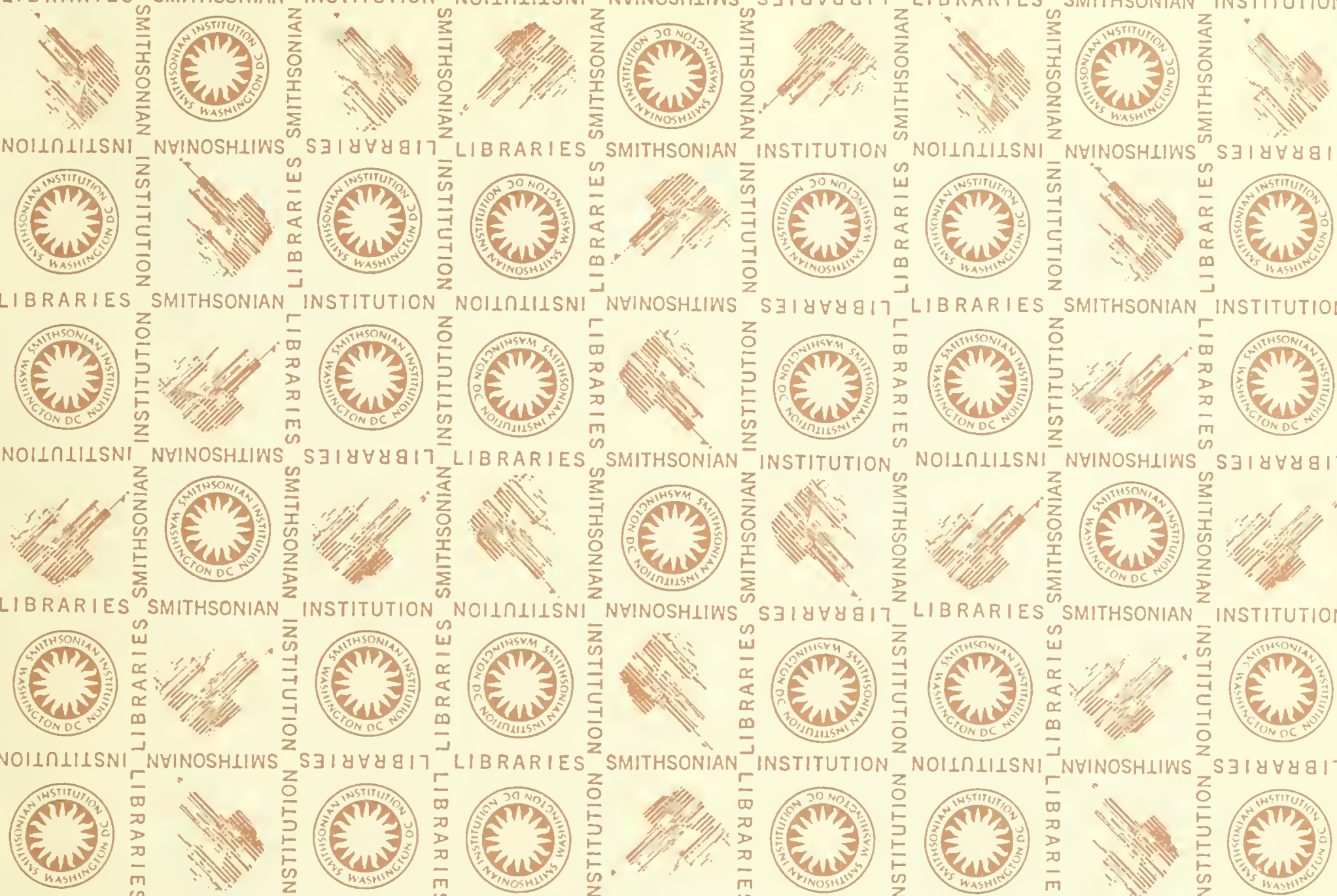

(a)
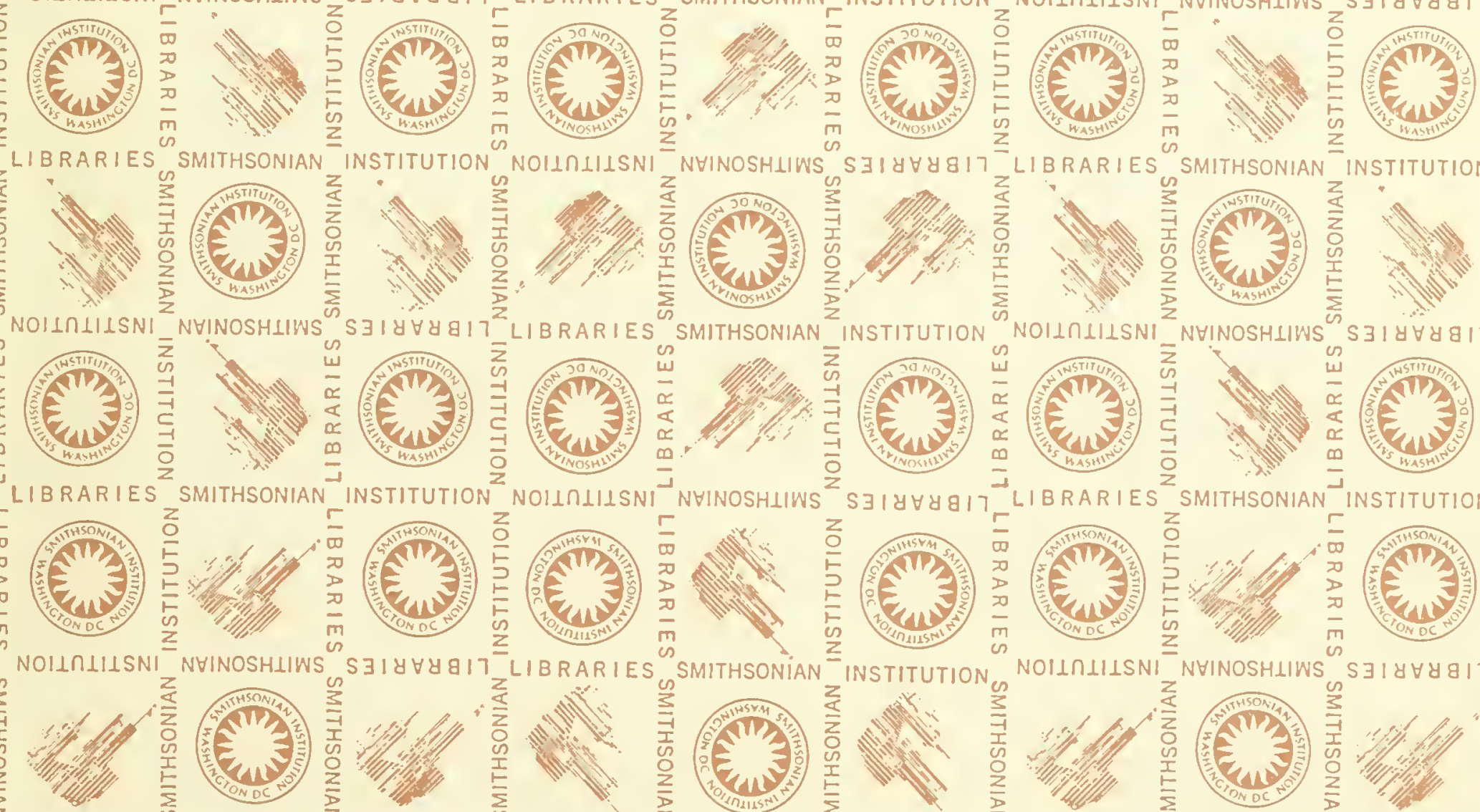
${ }^{2}$
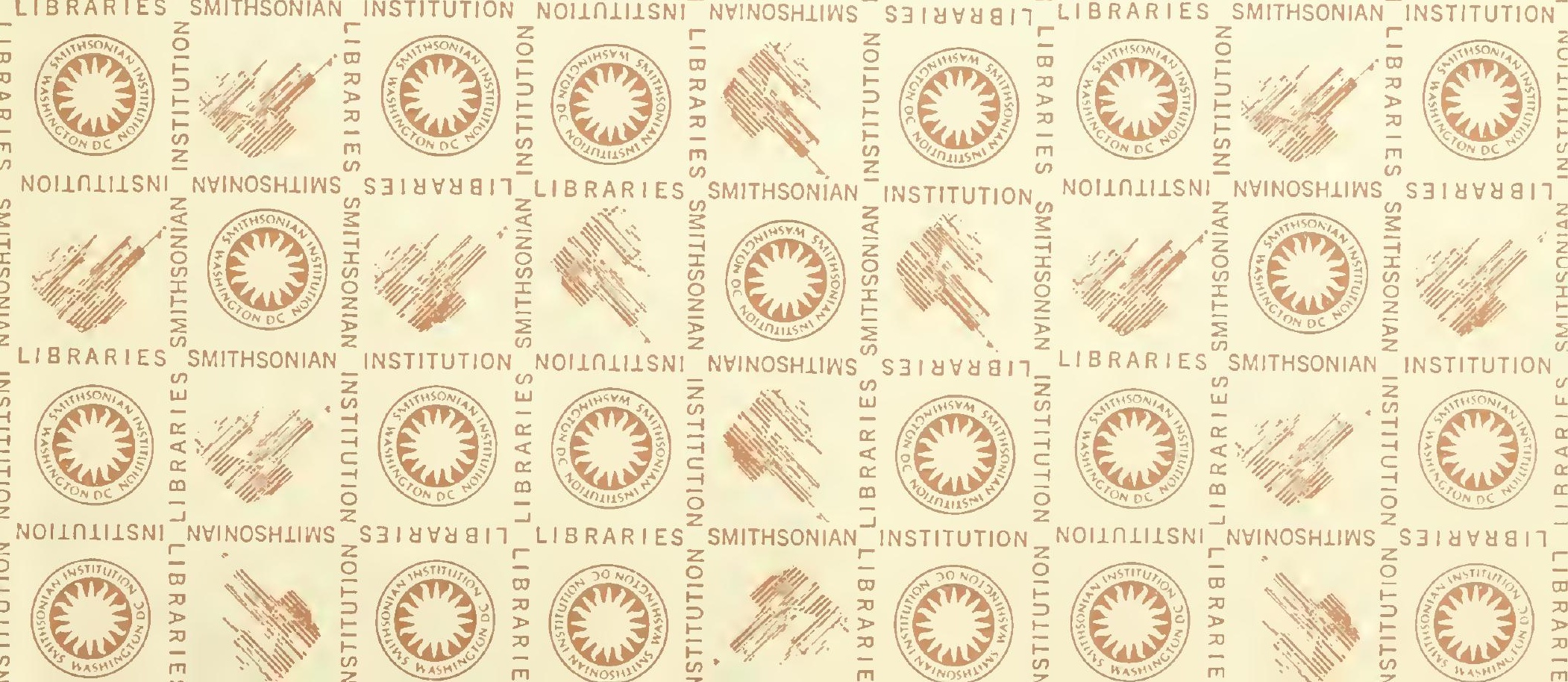



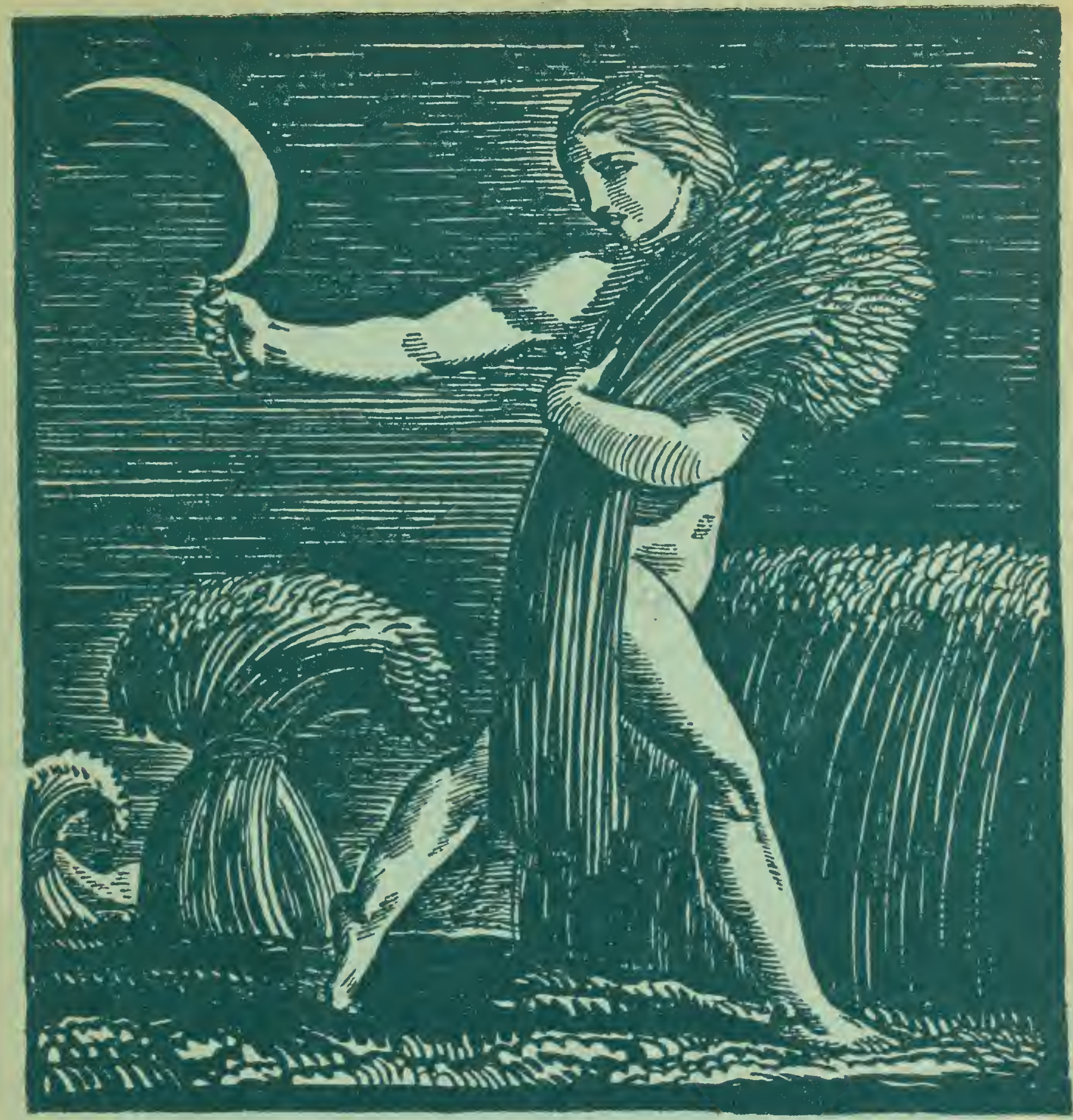

\section{EXHIBITION OF AMERICAN ART} CHAMBRE SYNDICALE

DE LA GURIOSITE ET DES BEAUX-ARTS 18, RUE DE LA VILLE-L'ÉVÊQUE.VIII'Ar. PARIS DIRECTRICE MARIE STERNER 


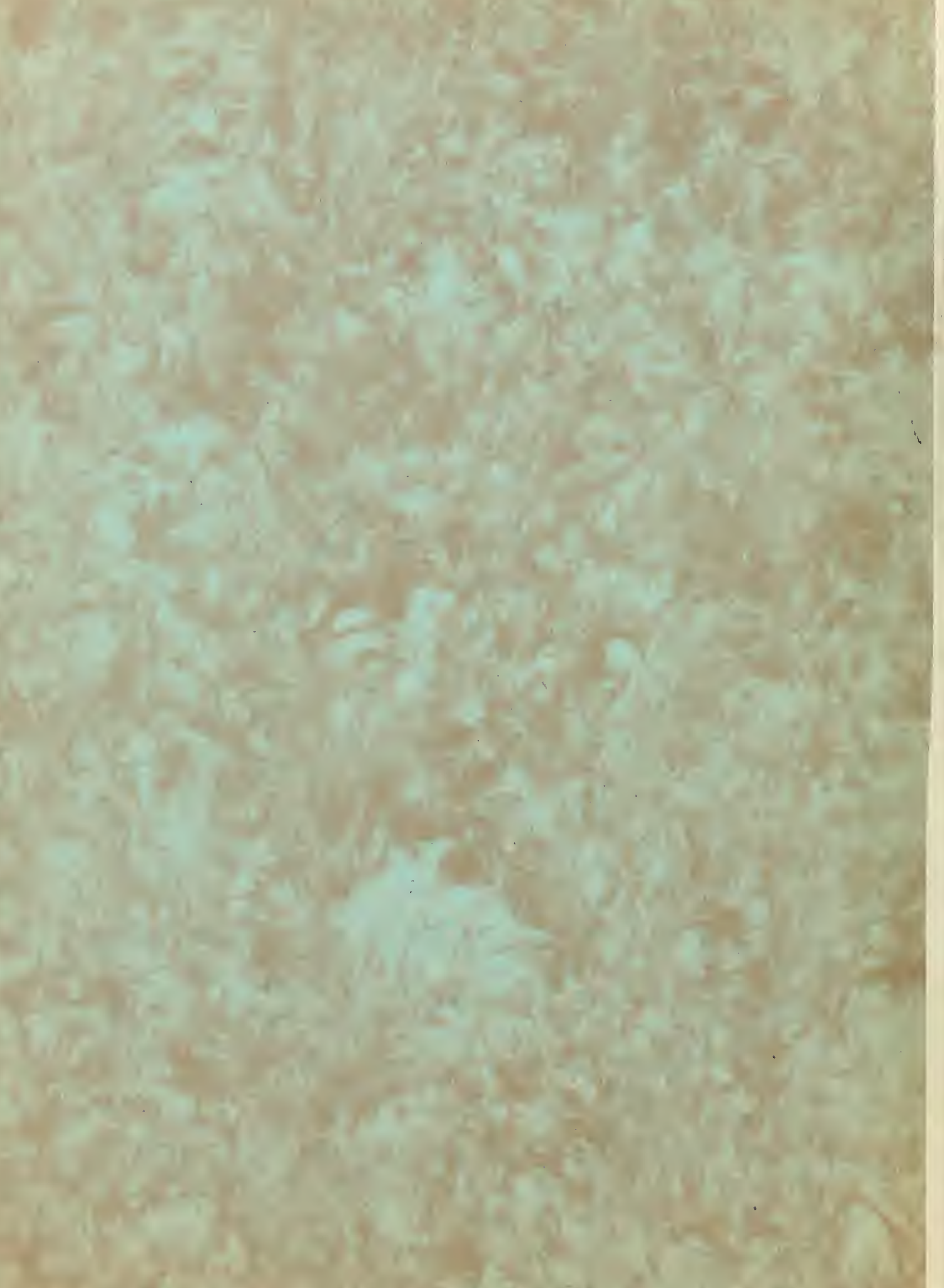




\section{ART PATRONS of AMERICA Inc.}

7o5, Fifth Avenue

\section{NEW-YORK City}

Mrs Wan. Payne THOMPSON Pres.

$M_{r s} E_{\text {gerton }} L$. WINTHROP VicePresident.

Mrs Meredith HARE Vice-President
Mrs Marie STERNER Director

Mrs Mauriel WINTHROP BOARDMAN Secretaire

Major Alaric SIMSON Treas.

\section{PATRONS}

Mrs Gordon W. ABBOTT

Mr Jules BACHE

Mr and Mrs Alfred BOSSOM

Mr Welles BOSWORTH

Mrs Leverett BR ADLEY

$M_{r}$ and $M_{r s}$ R. J. CALDWELL

Hon. Chauncey M. DEPEW

Mrs Walter FAR WELL

Mrs John W. GARRETT

$M_{r}$ and $M_{r s}$ C. DANA GIBSON

$M_{r}$ and $M_{r s} J_{o h u}$ Henry HAMMOND

$M_{r}$ and $M_{r s} R$. T. HAINES HALSEY

$\mathrm{Mr}_{\mathrm{r}}$ and $\mathrm{Mrs}_{\mathrm{r} \text { Horace HARDING }}$

Mr Adolpl LEWISOHN

$M_{r}$ and $M_{r s}$ Samuel LEWISOHN

$\mathrm{M}_{\mathrm{r}}$ and $\mathrm{M}_{\mathrm{rs}} \mathrm{H}_{\mathrm{H}}$ ry Fairfield OSBORN
Mrs Nathaniel Bowditch POTTER

Mr George Palmer PUTNAM

$\mathrm{Mr}$ and $\mathrm{Mrs}$ Alfred ROSSIN

$M_{r}$ and $M_{r s}$ Herbert SATTERLEE

$M_{r s} J$. Montgomery SEARS

$M_{r}$ and $M_{r s}$ Benson SLOAN

Mr John T. SPAULDING

Mrs Willard STRAIGHT

$M_{r s} W_{m}$ Payne THOMPSON

$M_{r s} W_{m} K$. VANDERBILT

Mrs A. Stewart WALKER

Mrs VANDERBILT WEBB

Mrs Payne WHITNEY

Miss Edith WETMORE

Mrs Egerton L. WINTHR OP

Miss Elsie de WOLFE 


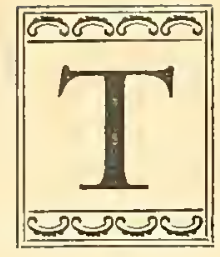

HE Art Patrons of America Inc. is an organization working for the co-operative interests of Artists and Patrons.

It was founded in 1921, as " $J_{\text {unior Art }}$ Patrons of America Inc". O wing to the fact that many adult collectors and connoisseurs are members of our organization the misapprehension caused by the word "Junior" made it seem advisable to change the name. The idea of interesting the younger generation in significant works of Art, which may be bought at reasonable prices, is still however, an important factor.

At the new galleries 705 Fifth Ave. We shall continue our policy of holding exhibitions of painting, sculpture, drawings and prints by distinguished Artists.

The Art Patrons of America acknowledge with deep gratitude the interest and able services of Mrs Muriel Boardman and Major Alaric Simson, and the great generosity of $\mathrm{Mrs}_{\mathrm{rs}} \mathrm{Wm}_{\mathrm{m}}$ Payne Thompson who has made this exhibition possible.

We also thank for their assistance $M_{r}$. Adolph Lewisoln, Mrs Alfred Rossin, Mrs Benjamin Stern and Mrs John W. Garrett.

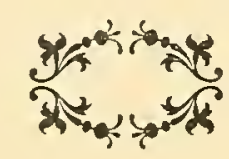


Galerie de la Chambre $S_{\text {yndicale des Beaux } \sim A_{\text {rts }}}$ 18, Rue de la Ville l'Évêque, à Paris

Exhibition of American Art, $J_{\text {une }} 9^{\text {th }}$ to $5^{\text {th }} \mathrm{Jul}_{\mathrm{u}}$ under the auspices of

The Art Patrons of America Inc.

\section{MARIE STERNER \\ Director}

\section{COMITÉ D'HONNEUR :}

His Exc. Mr MYRON T. HERRICK, Ambassador of U.S.A. in Paris.

S.A.R. la Princesse SIXTE de BOURBON.

Mme la Comtesse PaUl d'ARAMON.

Mme la Duchesse de BISACCIA.

Mme la Comtesse F. de CASTÉJA.

Mme la Comtesse A. de CHEVIGNÉ.

Mme la Duchesse de DOUDEAUVILLE.

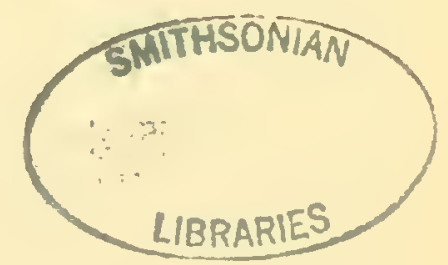

$M_{m e} P_{\text {AUl }}$ DUPUY.

Mme la Marquise de PRACONTAL.

Mine la Marquise de POLIGNAC.

$M_{\mathrm{r} s}$ SHELDON WHITEHOUSE.

M. L. BÉNEDITE, Conservateur du Musée du Luxembourg.

M. le Comte Etienne de BEAUMONT.

M. WALTER BERRY.

M. le Marquis de CASTELLANE.

M. Francis de CROISSET.

M. le Duc de GUICHE. 


\section{$\begin{array}{llllllll}\mathrm{F} & \mathrm{O} & \mathrm{R} & \mathrm{E} & \mathrm{W} & \mathrm{O} & \mathrm{R} & \mathrm{D}\end{array}$}

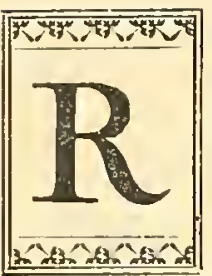

ECENT EVENTS seem to have stimulated the emotional life of the American people to such a degree that they find it hard to fall back into the complacency of their former living. The old security in ease and comfort seems suddenly insufficient, and there is a general searching for more enduring values, and a scrutiny of the nation's resources, spiritual as well as material. We have been in the habit of looking overseas for artistic guidance, but now, unsuspected among us, our artists have been at work setting down a record of our deeper virtues.

The inauguration of the Art Patrons of America comes quite opportunely with this awakened recognition of the artist as the one among us, who can best give expression to those ardors and aspiration which have animated our national life from its begimnings. This Exhibition of American Art is in the way of a mirror making reflection of our truest and most abiding qualities. Here are the visions of our native painters and sculptors translated, and made tangible and visible to us; all together they form a picture of us by which we will be judged by future generations.

It is impossible to view this exhibition without just pride. I believe that many people who visit these halls will be amazed at the mumber of individual works which stand forth as masterworks. The cumulative greatness of American art is here revealed, not as a grand national style, but as the emergence of a series of brilliant individuals. The exigencies of the pioneer life, and the lack of a cultural tradition, made early contact with European influences inevitable. In fact, it was the contact of those pioneer artists with European culture which mitigated the deep provincialism of our early national life. Even today we suffer more from lack rather than surfeit of cultural rapport with the older countries; and we still have much to learn from our own artists whobring us the breadth of their cosmopolitanism. Modern tendencies in art are less and less national in the narrow sense, and the separate cults and schools have their devotees in various countries quite regardless of geographical boundaries.

Yet the pictures hung in this exhibition are imbued with qualities that are essentially American. You get a sense of some tremendous vitality pervading these canvasses, of an emotional energy that has scarcely been tapped. You feel that these men have deep sources to draw from, and that especially the young moderns are very near to their sources. The new spirit, the new knowledge, the new liberation in the arts, have put a power into the hands of our artists to express the truth and beauty of America as it has never been told before.

If you are one who harbors a faith in the high spirit of America, you will acknowledge a loyalty and gratitude toward these men and women who are saying such fine things for their country. It will come to you poignantly that these are ours, and that you want to give them your encouragement and support. 


\section{List of Paintings for $\mathrm{P}_{\text {aris }}$ Exhibition}

\section{PAINTINGS}

\begin{tabular}{|c|c|c|}
\hline BARBER (John). & $\begin{array}{l}1 \\
2\end{array}$ & $\begin{array}{l}\text { Painting } \\
\text { Painting }\end{array}$ \\
\hline BARTLE'T (Frederick). . & $\begin{array}{l}3 \\
4\end{array}$ & $\begin{array}{l}\text { Venetian Salon } \\
\text { Bernini Fountain }\end{array}$ \\
\hline BEAL (Gifford) . . . . & $\begin{array}{l}5 \\
6 \\
7\end{array}$ & $\begin{array}{l}\text { Circus } \\
\text { Deep Sea Fishing } \\
\text { Hauling Nets }\end{array}$ \\
\hline BELLOWS (George). & $\begin{array}{l}8 \\
9 \\
10 \\
11 \\
12 \\
13 \\
14 \\
15 \\
16 \\
17 \\
18 \\
19 \\
20 \\
21 \\
22 \\
23\end{array}$ & $\begin{array}{l}\text { Portrait of My Mother } \\
\text { Emma and Her Children } \\
\text { Crucifixion } \\
\text { Old Lady of } 1860 \\
\text { Fishermans Family } \\
\text { Interior of My Studio } \\
\text { Anne in White } \\
\text { Landscape. Dead Tree } \\
\text { Gramercy Park } \\
\text { Emma in Purple } \\
\text { John Sullivan } \\
\text { Easter Snow } \\
\text { On the Porch } \\
\text { The Big Dory } \\
\text { Nude } \\
\text { Landscape. Autumn Brook }\end{array}$ \\
\hline
\end{tabular}

BECKER (Maurice). . . . . 24 In Mexico City

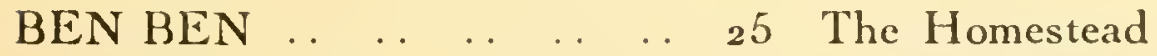

BERNSTEIN (Theresa) . . . $\quad 26$ New England Town

BIDDLE (George) . . . . . . $\quad 27$ Landscape. Tahiti

28 Bathers

Information regurding condition of dales al special discount and free delivery of piclures to any ourl of Europe or tbe United Statis may be bad by inquiring at the desk. 


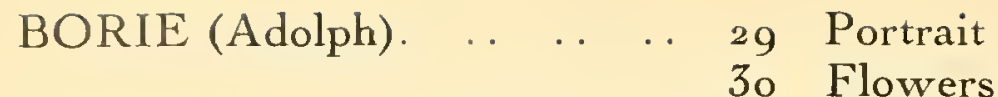

BOUCHE (Louis) .. $\quad . \quad \ldots \quad$. 31 The Nut

32 Mamma's Boy

BRUMBACK (Louise-Upton). 33 Dog Town Common

34 Harbour in Winter

BURLIN (Paul). . $\quad . \quad \ldots \quad . \quad . \quad 35$ Portrait of E. B.

36 Landscape

CHANLER (Robert). . . $\quad . \quad 37$ Screen

38 Decoration

COMINS (Eben F.).. $\quad . \quad \ldots \quad 39$ The Sunday Edition

DAVEY (Randall) .. . . . . 40 Johnny Lynch

DAVIES (Arthur B.). .. . . 41 Caliban Seas

42 Daphnes of The Ravine

43 Minor Syllables

44 Under The Trees

45 Untouched Yet Touch

46 Earths Throat's Edge

47 Multiple Youth

48 On The Cliffs

49 Avatar

5o Maenad Arabesque

51 Child's Portrait

52 Moonbeam

53 Tremulous Leaves

54 The Moonstone.

Loaned by Mrs Meredith Hare

DOUGHERTY (Paul) . . . 55 Painting

56 Painting

DU BOIS (Guy Pene) . . . 557 Portrait

FAULKNER (Barry). . . $\quad . \quad 58$ Decoration

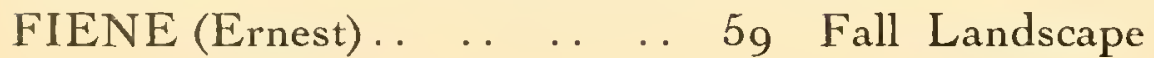

Information regarding condilion of ales al special discount and free delivery of pictures to any part of Europe or the United States may be bad by inquiring at the desk. 
GAY (Walter) .. .. . . . . 60 Interior chez Helleu

GLACKENS (William) .. .. 61 At Mouquin's

62 Dahlias

GREENMAN (Frances). . . 63 Portrait

GOLDBECK (Walter).. .. 64 Portrait of Walter Rummel

65 Flowers. Still Life

GENTH (Lillian). . . . . . $\quad 66$ Cliffs of The Pacific

GOLINKIN (J. W.). . . $\quad . \quad 67$ The Negro

68 In the Gulf Stream

GUSSOW (Bernard). . . . . 69 Concert on Columbia Green

HALE (Gardner). . . . . . . 70 San Gimigniano

HALPERT (Samuel) . . . . 7 1 East River Pier

72 The Pink Curtains

73 Saint Tropez

HARTMAN (Bertram) .. .. 74 Going Up

75 Skyscrapers. New-York

76 New-York

HAWTHORNE (Charles) .. 77 Purple and Green

HIGGINS (Eugene) . $\quad \ldots \quad \ldots \quad 78$ Far West

79 Pueblo Indians

8o Nativity

$\operatorname{KELLER}\left(H\right.$. G.) $\quad \ldots \quad \ldots \quad \ldots \quad 8_{1}$ Evening on Grenada Road

KENT (Rockwell) . . . . . $\quad 82$ Down to The Sea

83 Maine. (Loaned by the late Robert P. Perkins Esq).

84 In Alaska

KOPMAN (B.) . $\quad \ldots \quad \ldots \quad \ldots \quad 85$ Philosopher

86 Philosopher Resting

87 Landscape

Information regarding condition of sales at special discount and free delivery of pictured to any part of Europe or the United Stated may be had by inquiring at the didk. 
$\begin{array}{rllllll}\text { KROLL (Leon) .. } & \ldots & \ldots & \ldots & 88 & \text { Building New-York } \\ & & & 89 & \text { In New-York } \\ & & 90 & \text { Mulberry Road } \\ & & & \\ & & & \\ & & 92 & \text { The Falls } \\ & & & \end{array}$

KRONBERG (Louis) . . . . $\quad 93$ Ballet Dancer

KUEHNE (Max). $\quad \ldots \quad \ldots \quad \ldots \quad 94$ The Mill

$9^{5}$ Alhambra

KUHN (Walt). .

97 Figure Inclined Head

98 Head

99 The Sleeping Girl

100 Indian Commissioners

10 Plants. - Flowers

KUNYOSHI $\quad . \quad \ldots \quad \ldots \quad \ldots \quad 102$ Baby

103 Cows in Pasture

LEVER (Hayley) . . . . . . 104 The Draw Bridge

105 Storm Effect

LECHAY (Myron) .. . . . . 106 Gloucester

LIE (Jonas)..

108 Driftwood

LOGAN (Robert Fulton) . . . 109 Landscape

LUKS (George) .. . . . . . . 110 The Fortune Teller

MATULKA (J.). . .

MAURER (Alfred) . . $\quad . \quad \ldots \quad 112$ Single Figure

1 3 Two Figures

MAC FEE (Henry).. .. .. 114 Portrait

115 Still Life

MEYEROWITZ (William).. 116 Fishing Village

Information regarding condition of sales at special discount and free delivery of pictures to any oart of Europe or the United Slates may be bad by inquiring at the desk. 

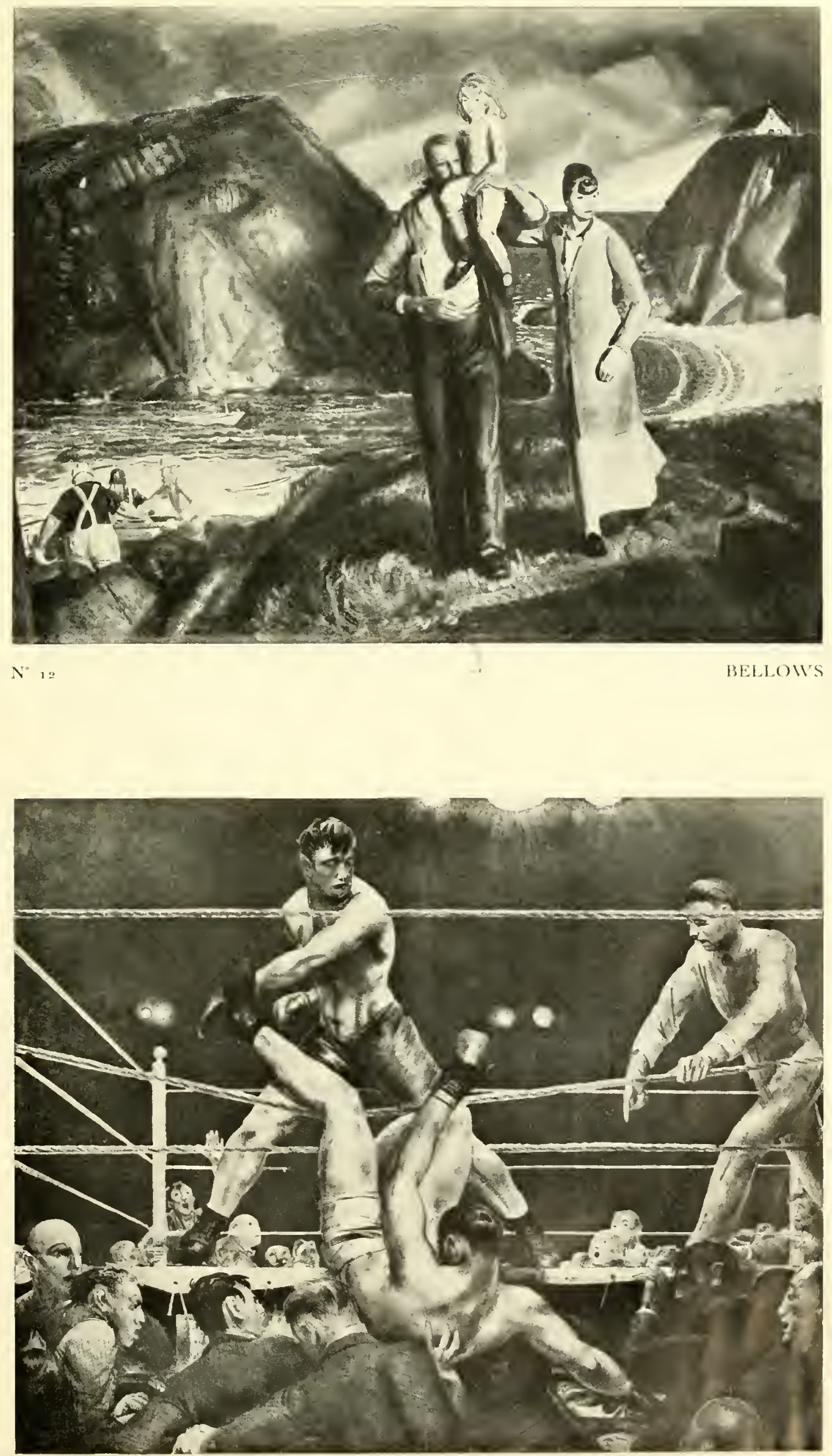


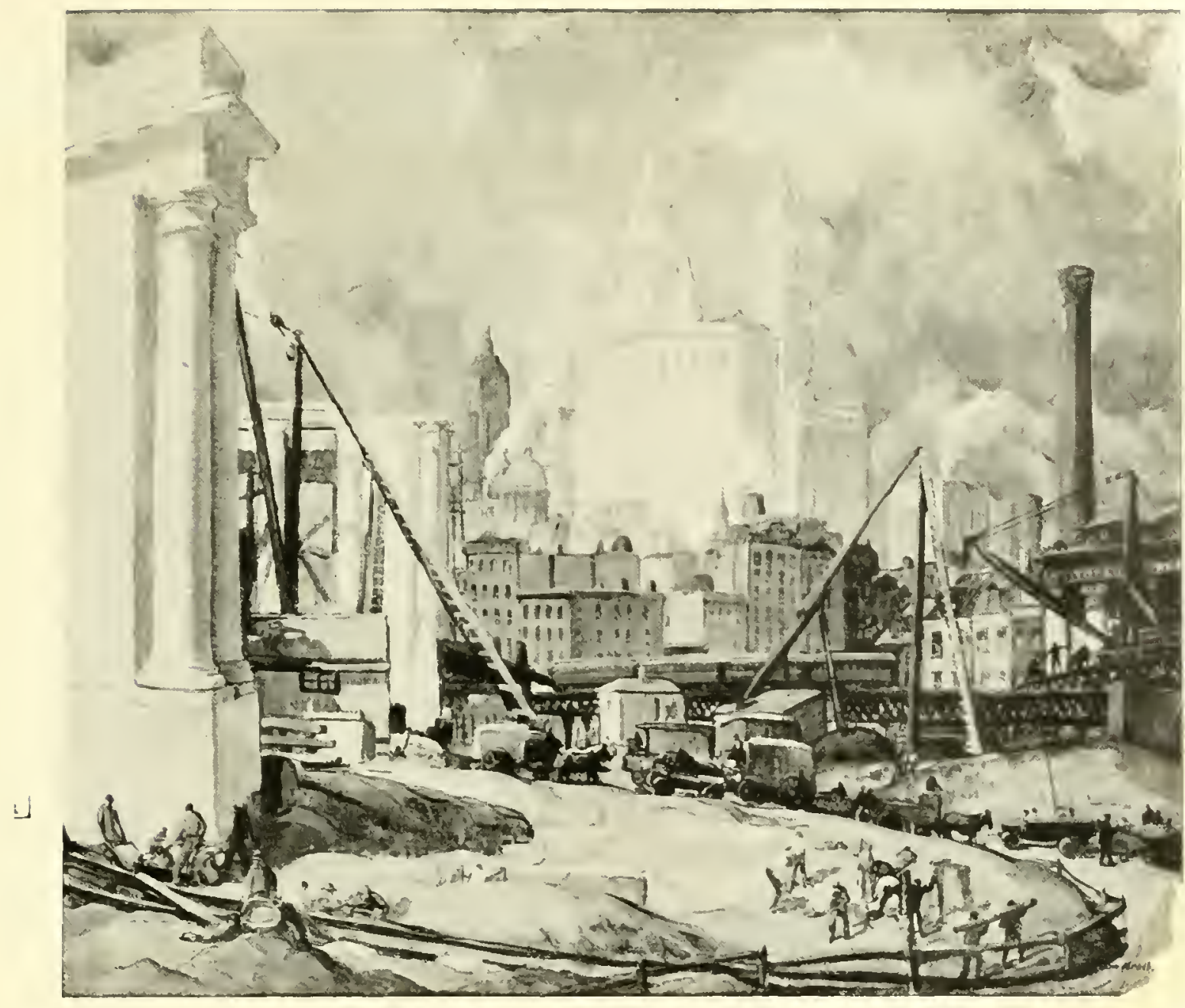

$N{ }^{2} S_{9}$

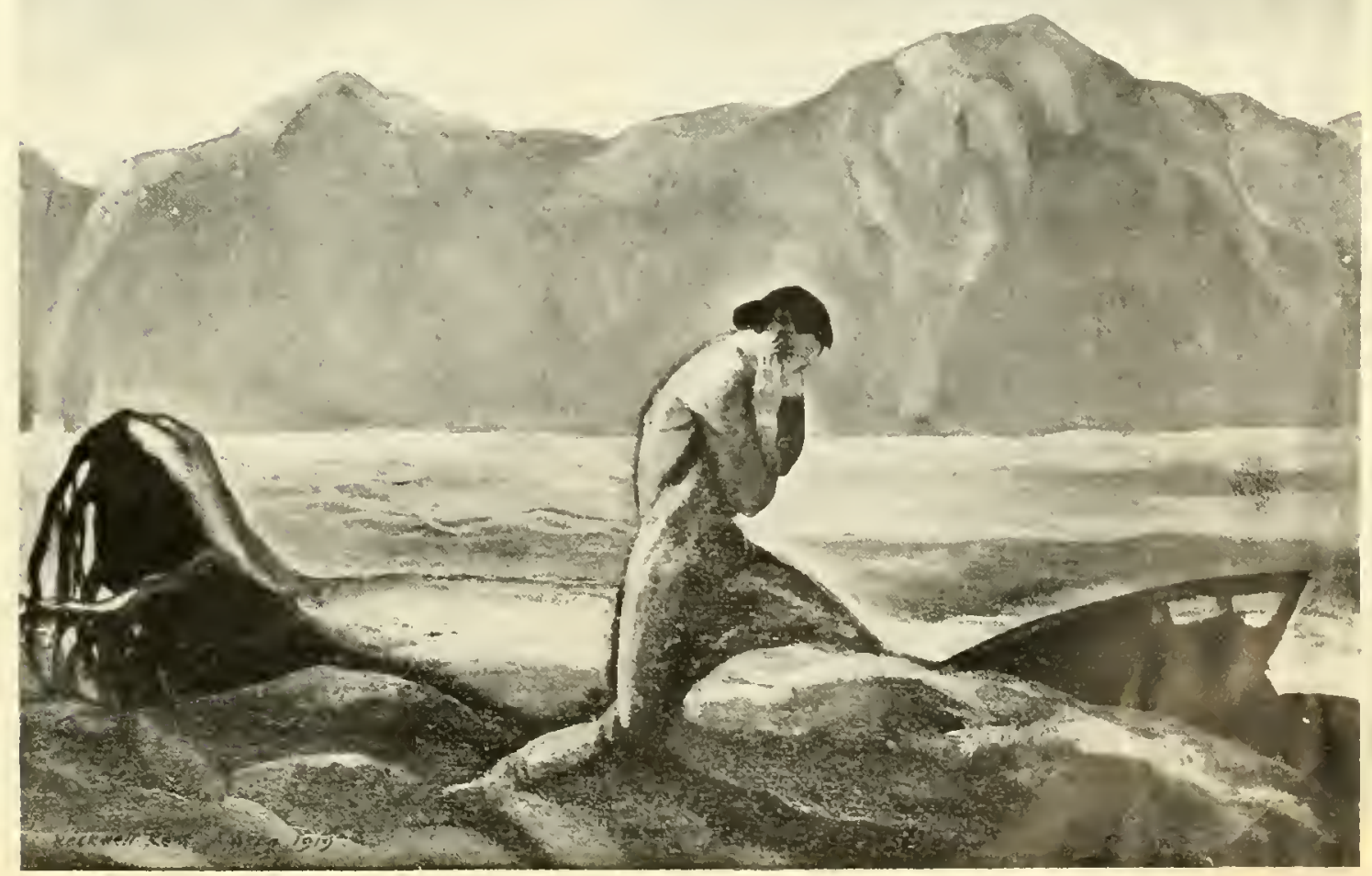




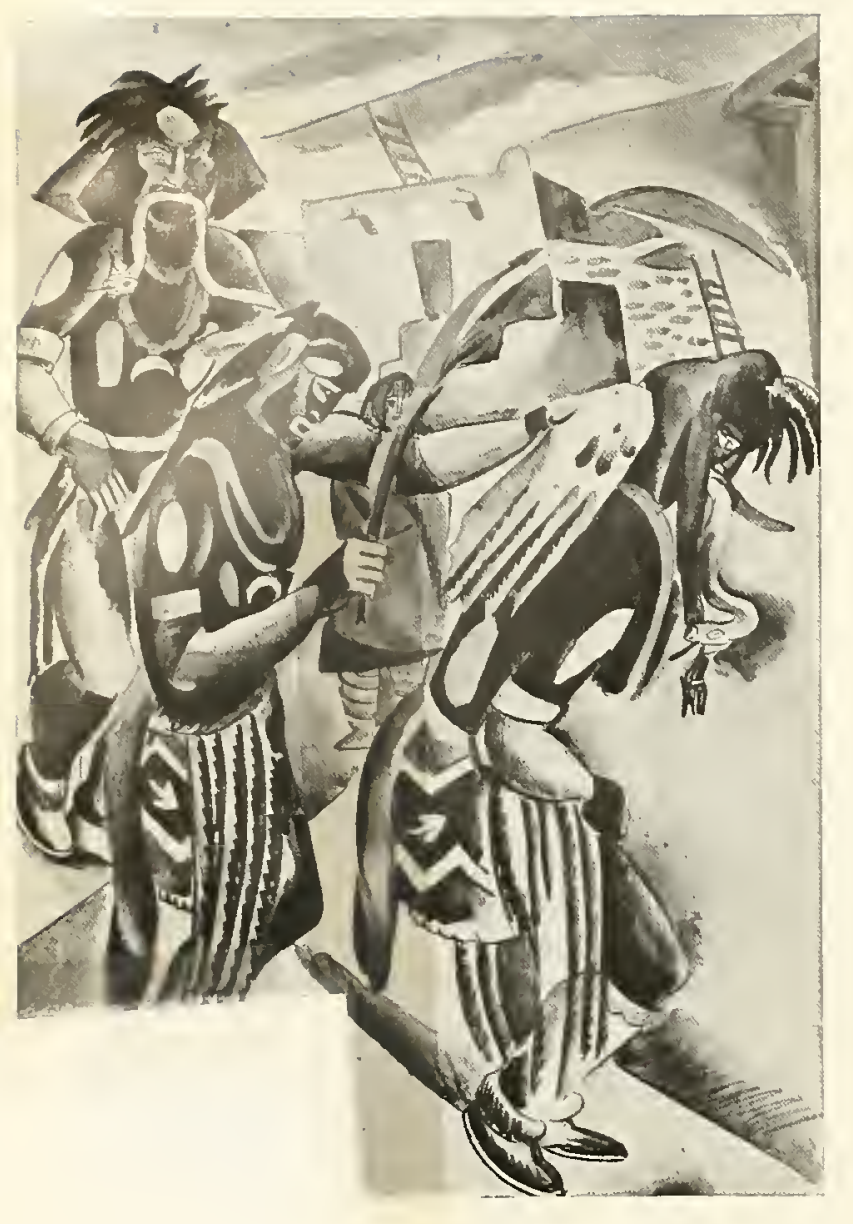

MATULKA

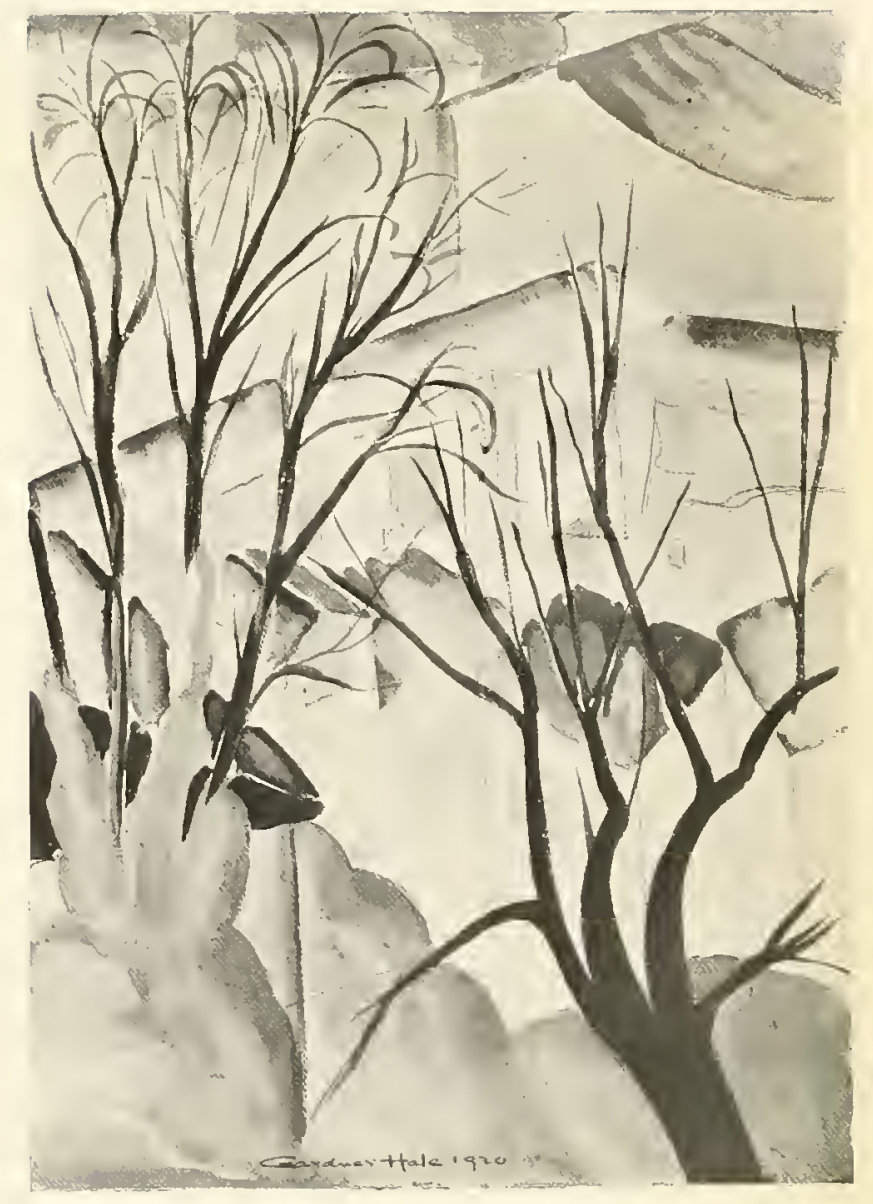

$N^{\circ} \quad 189$

HALE
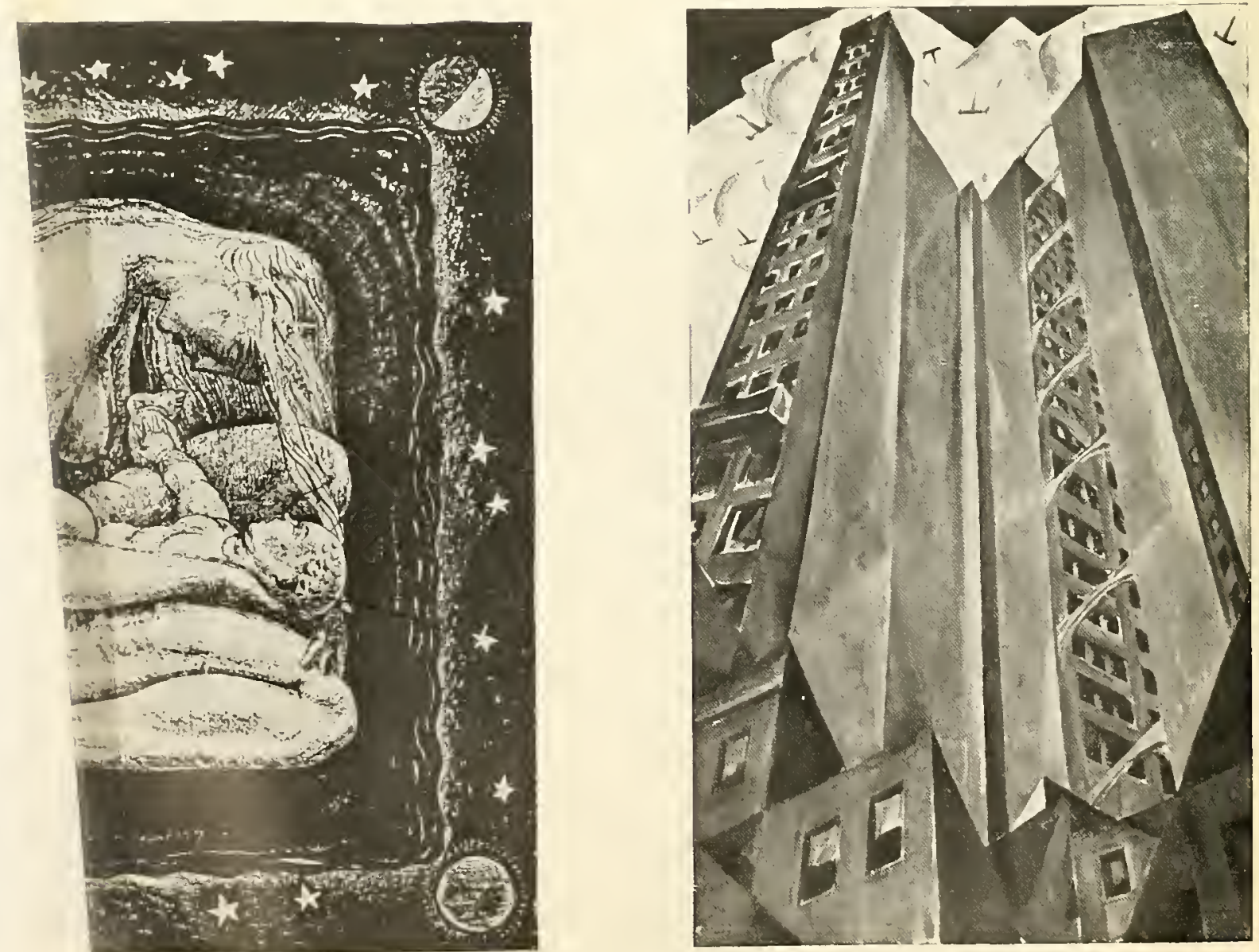


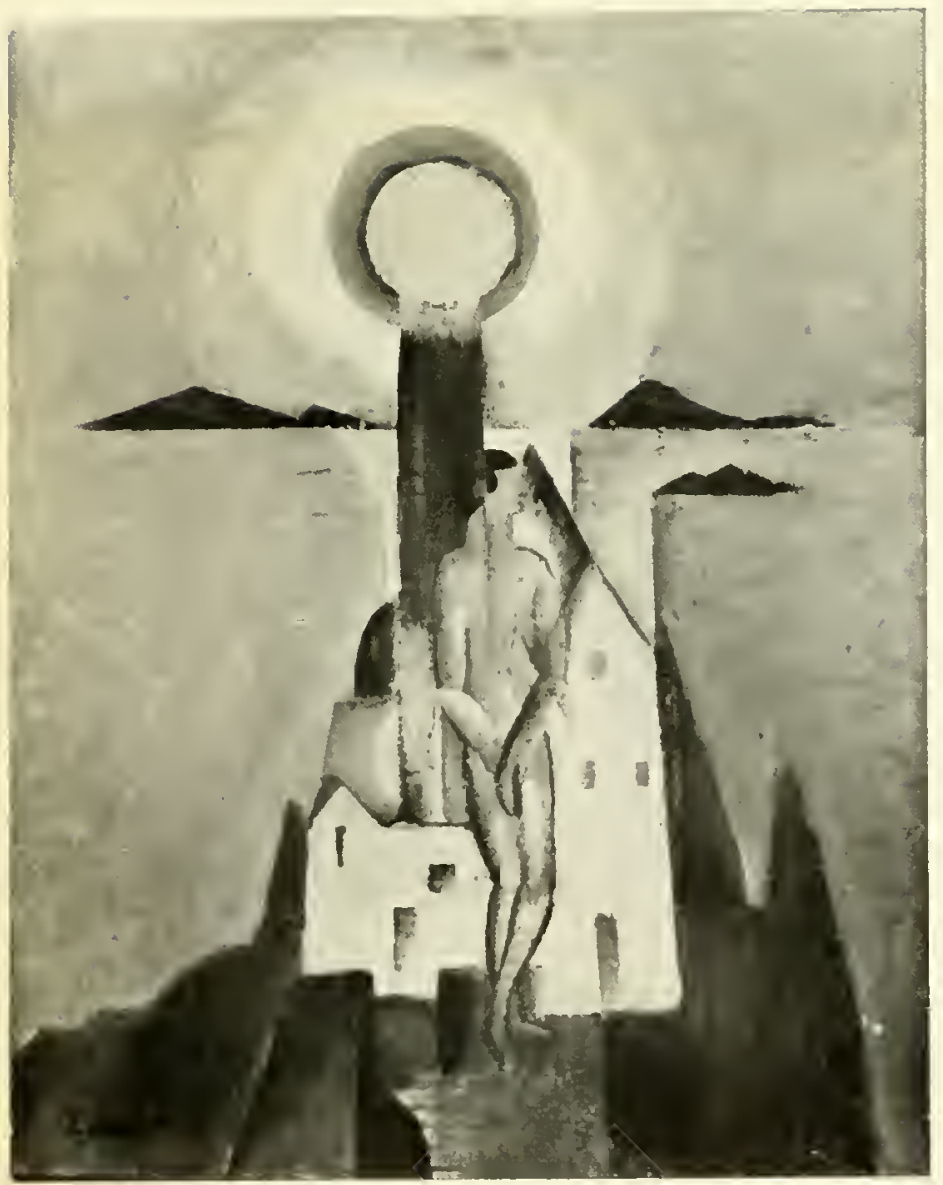

1161

ZOR.ICII

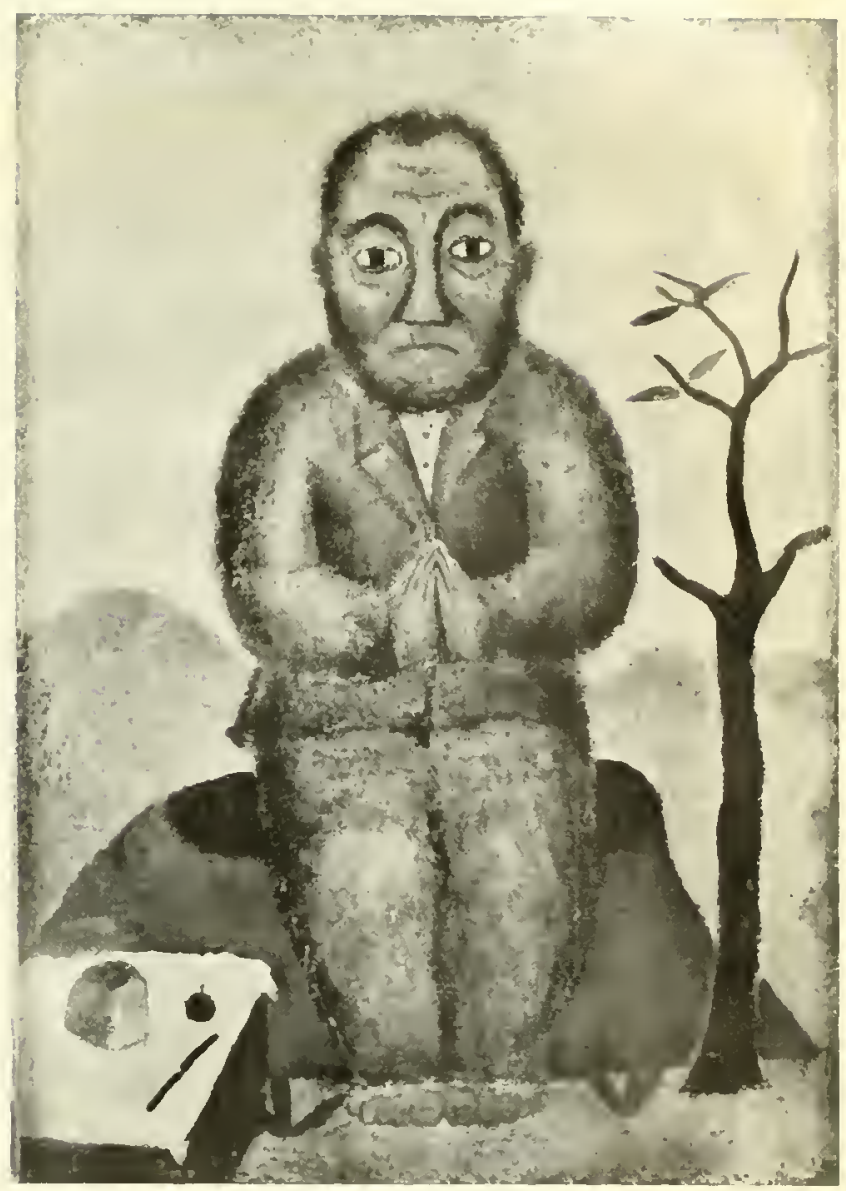

N.85

KOMNAN
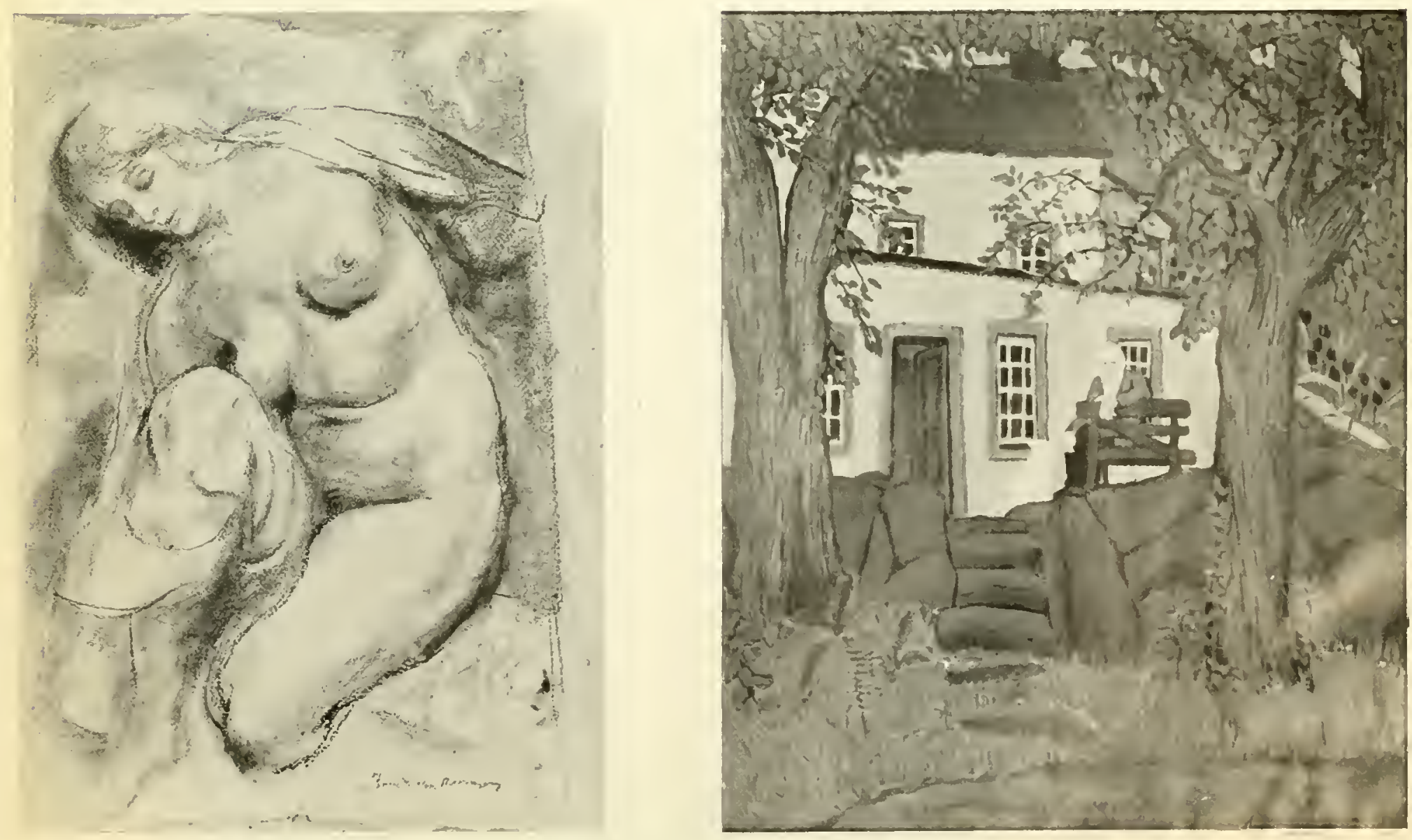

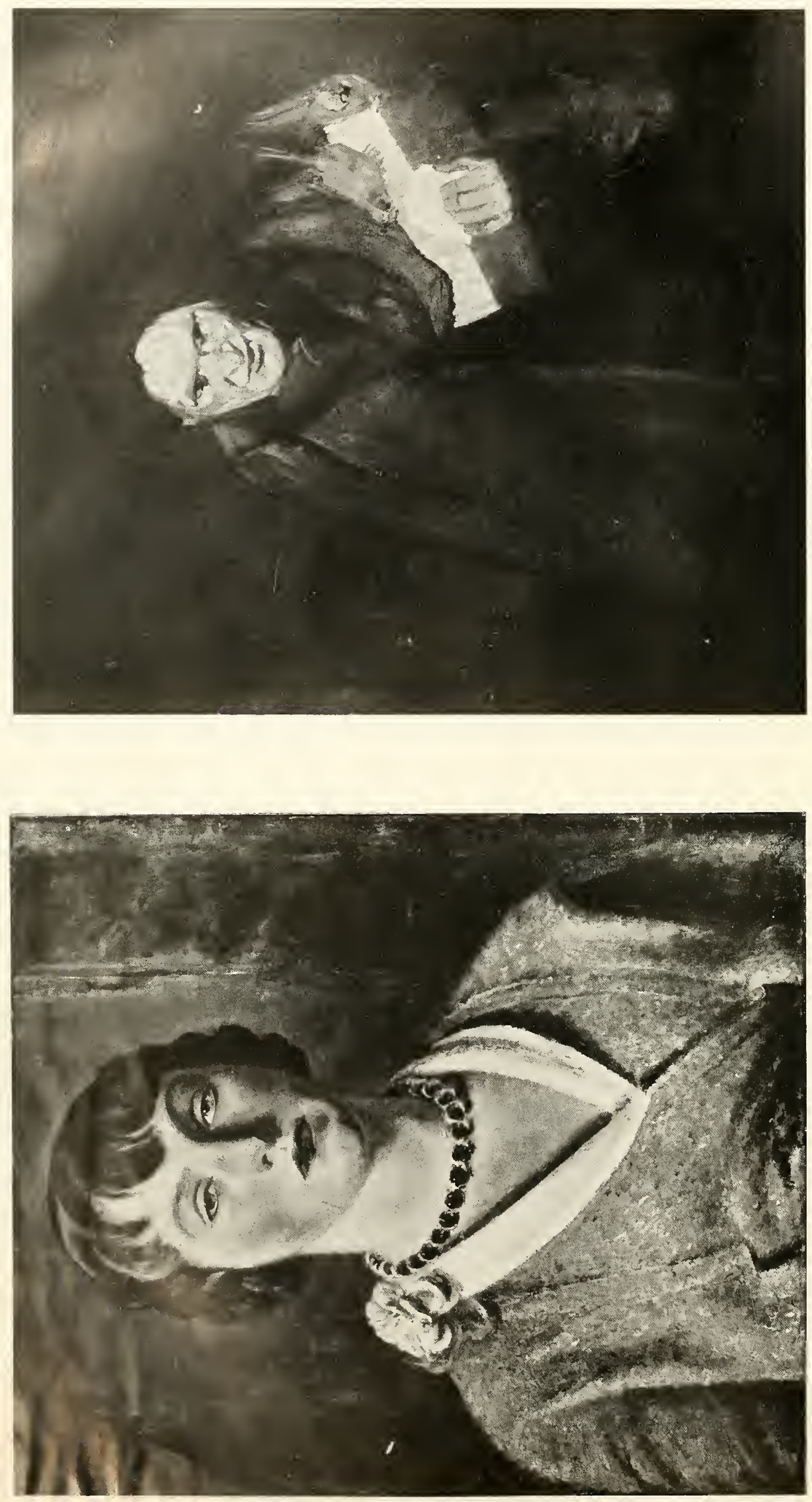

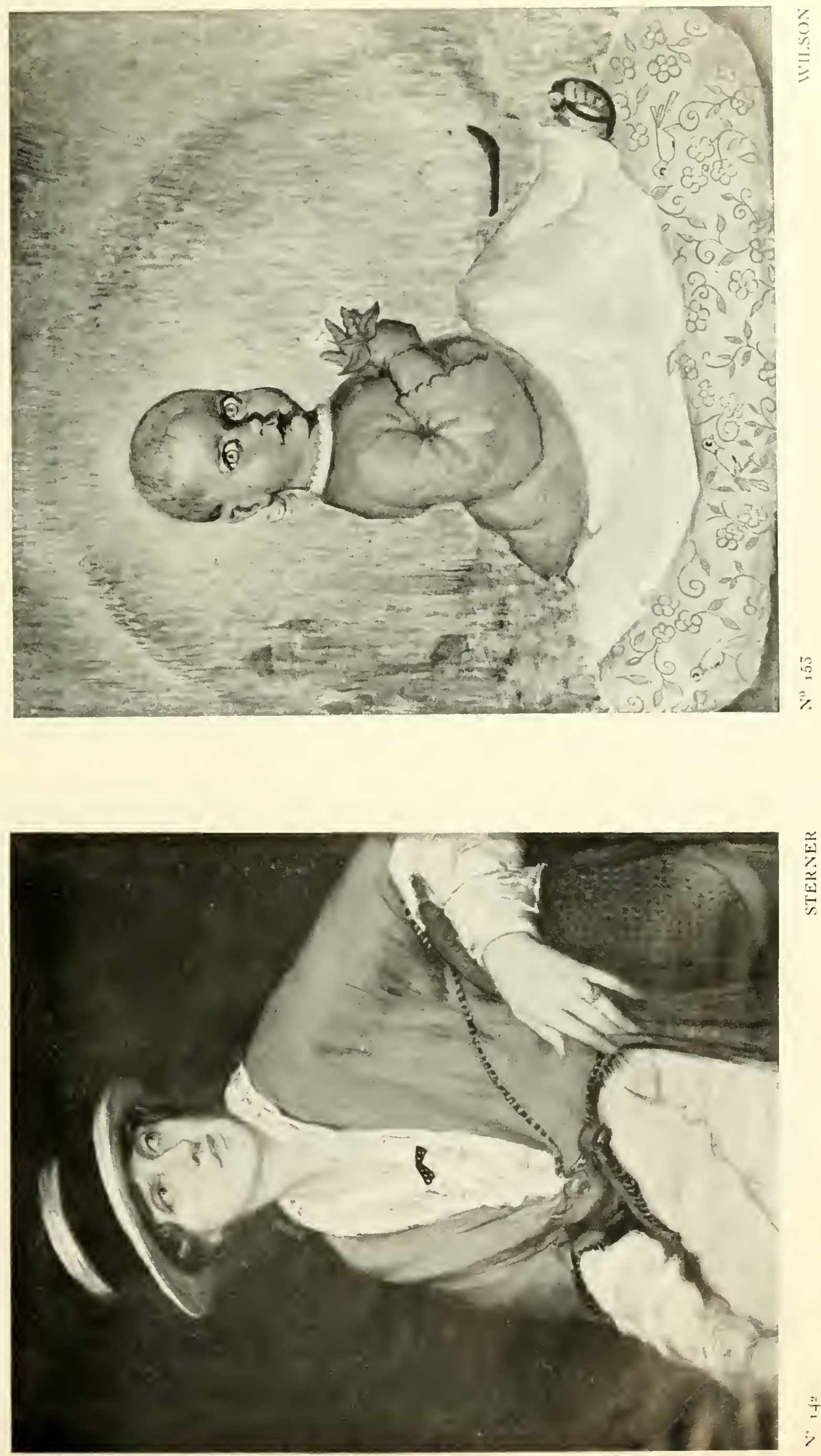

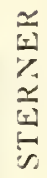



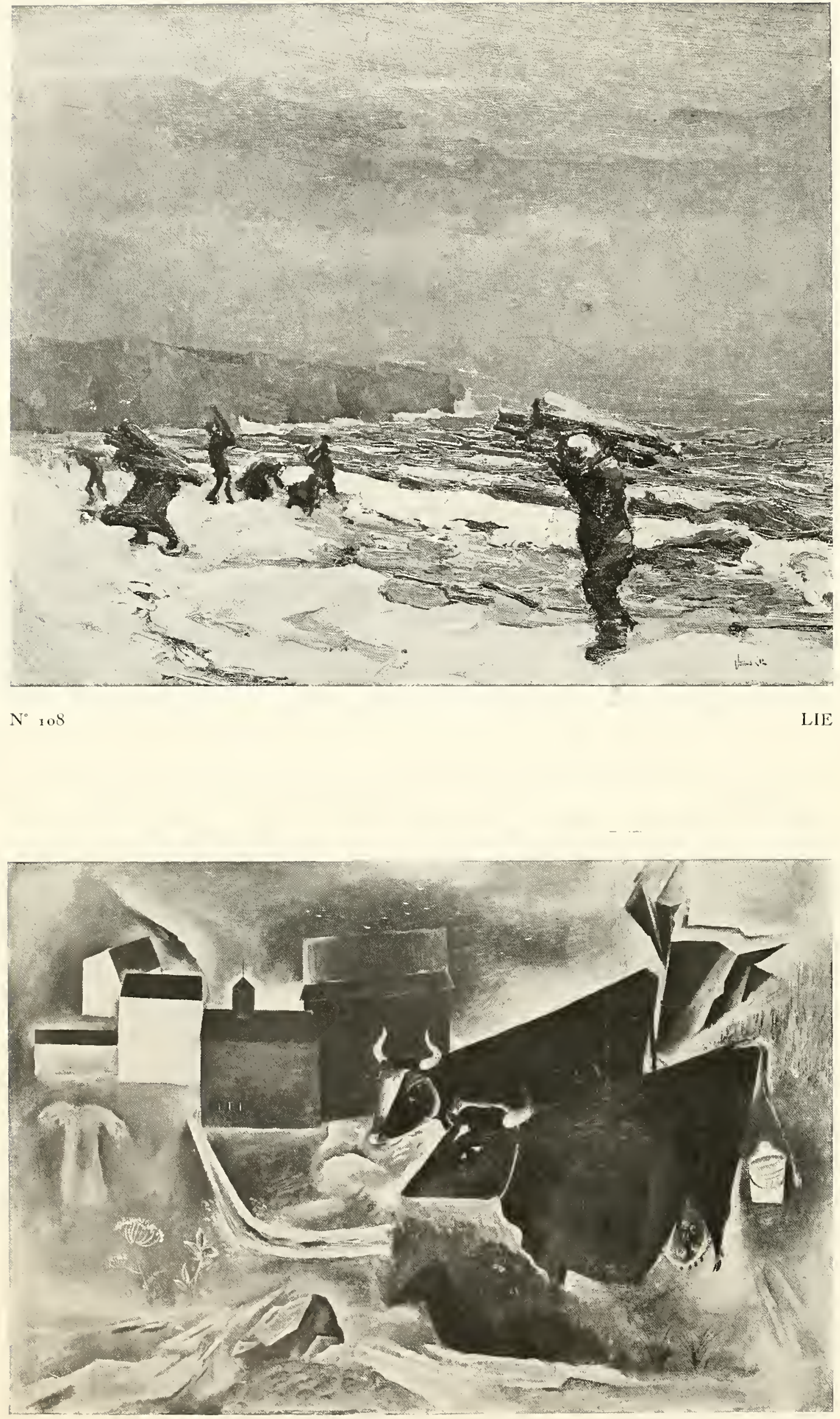

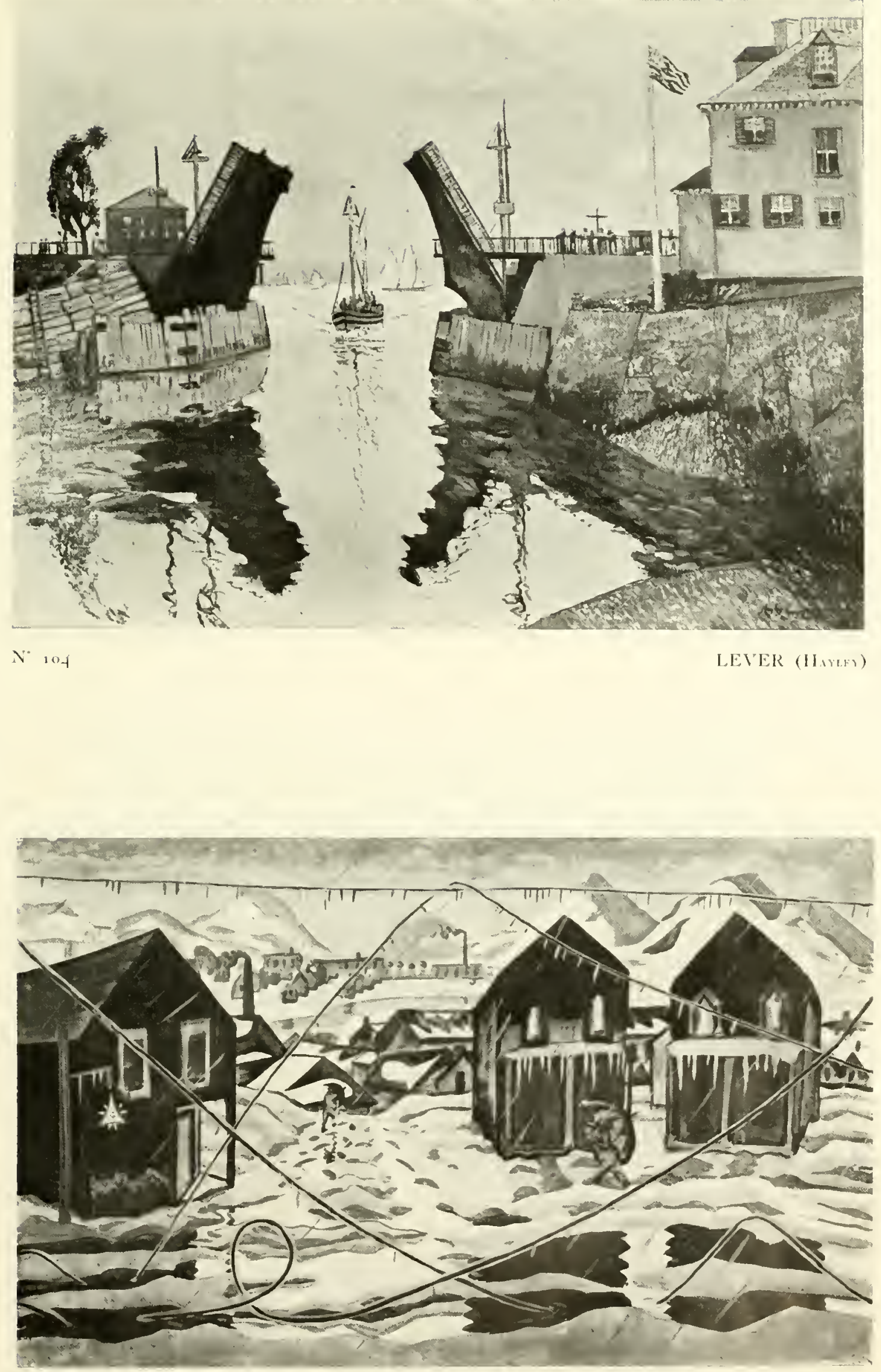

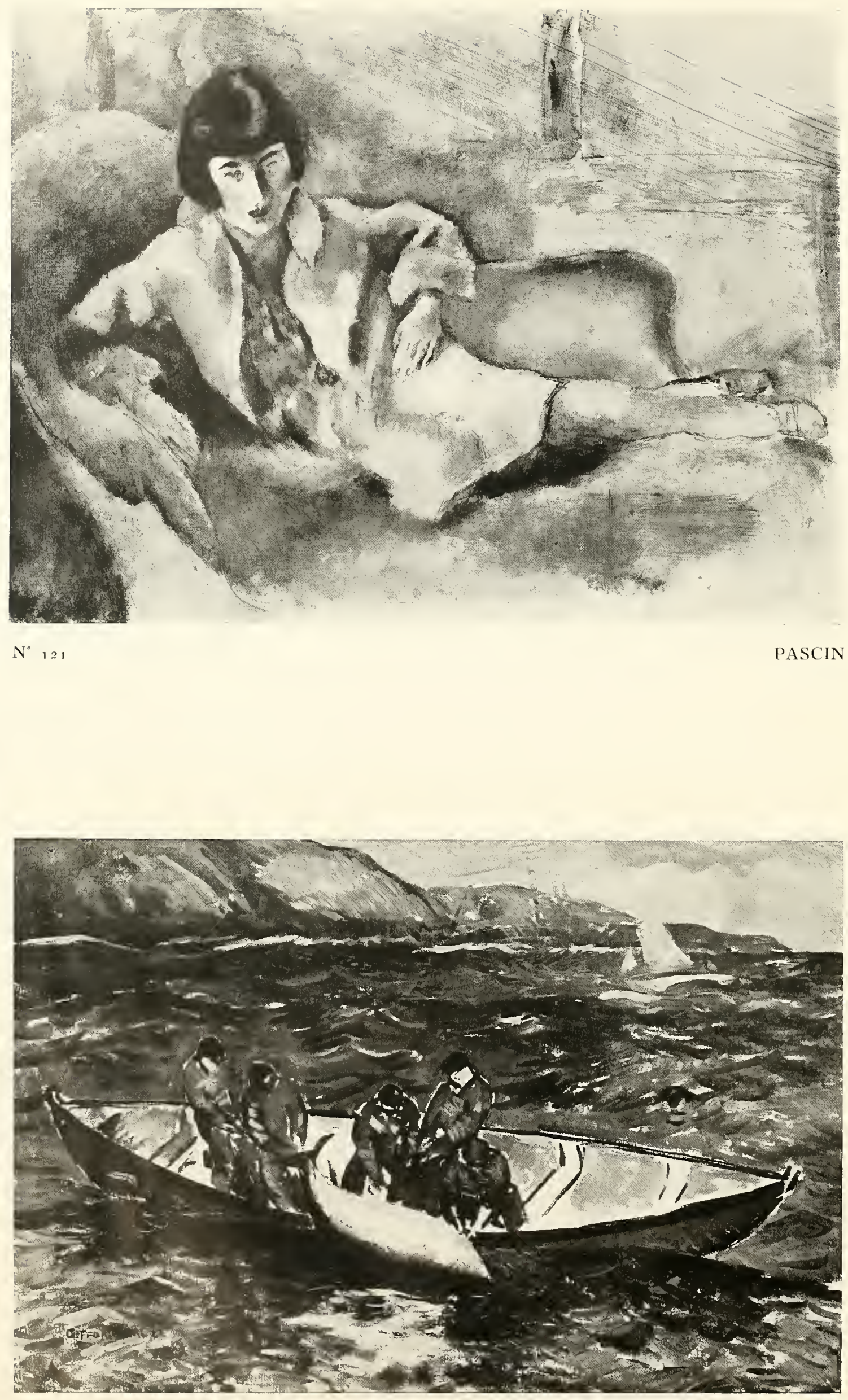


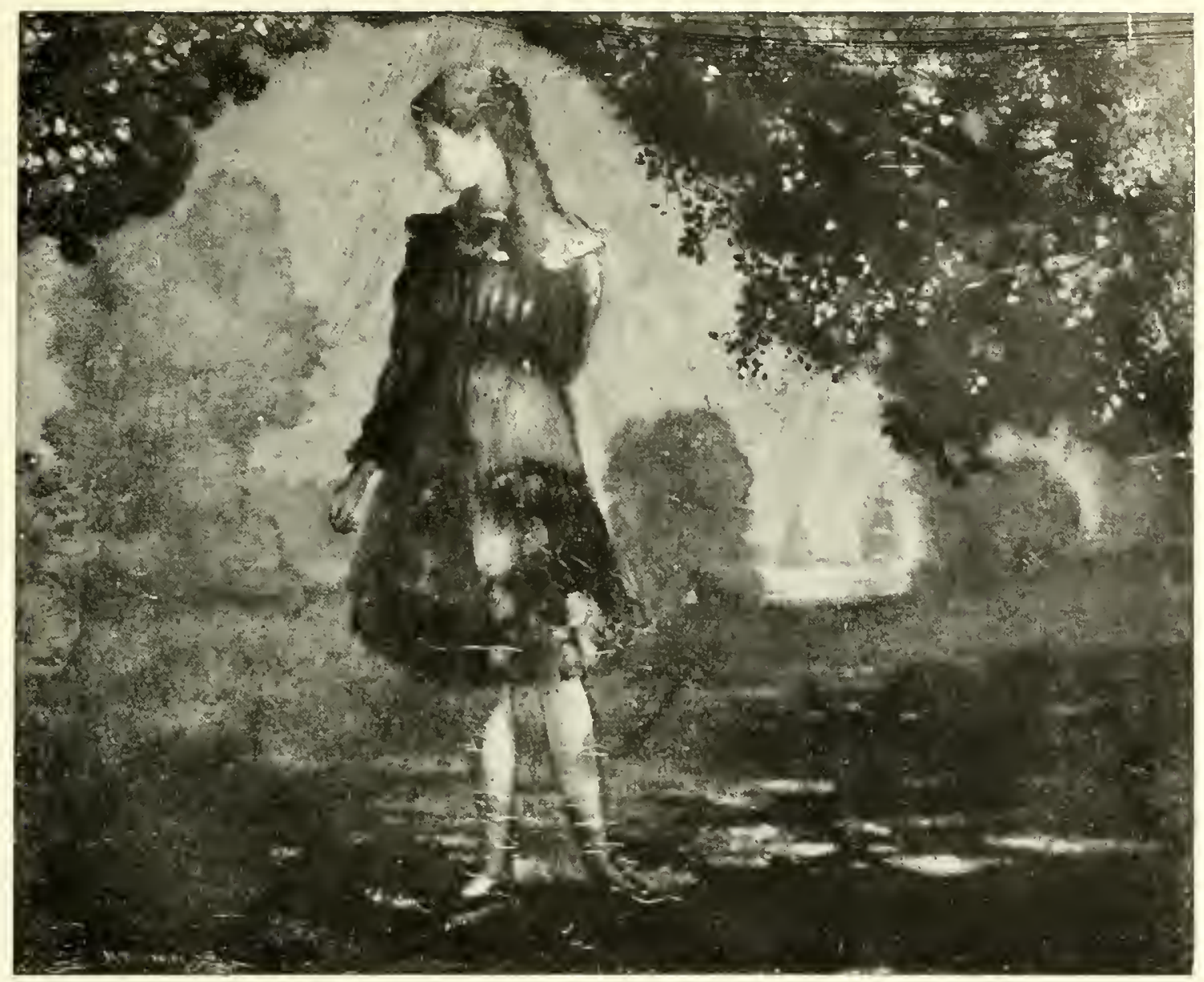

N 51

1) AVIES

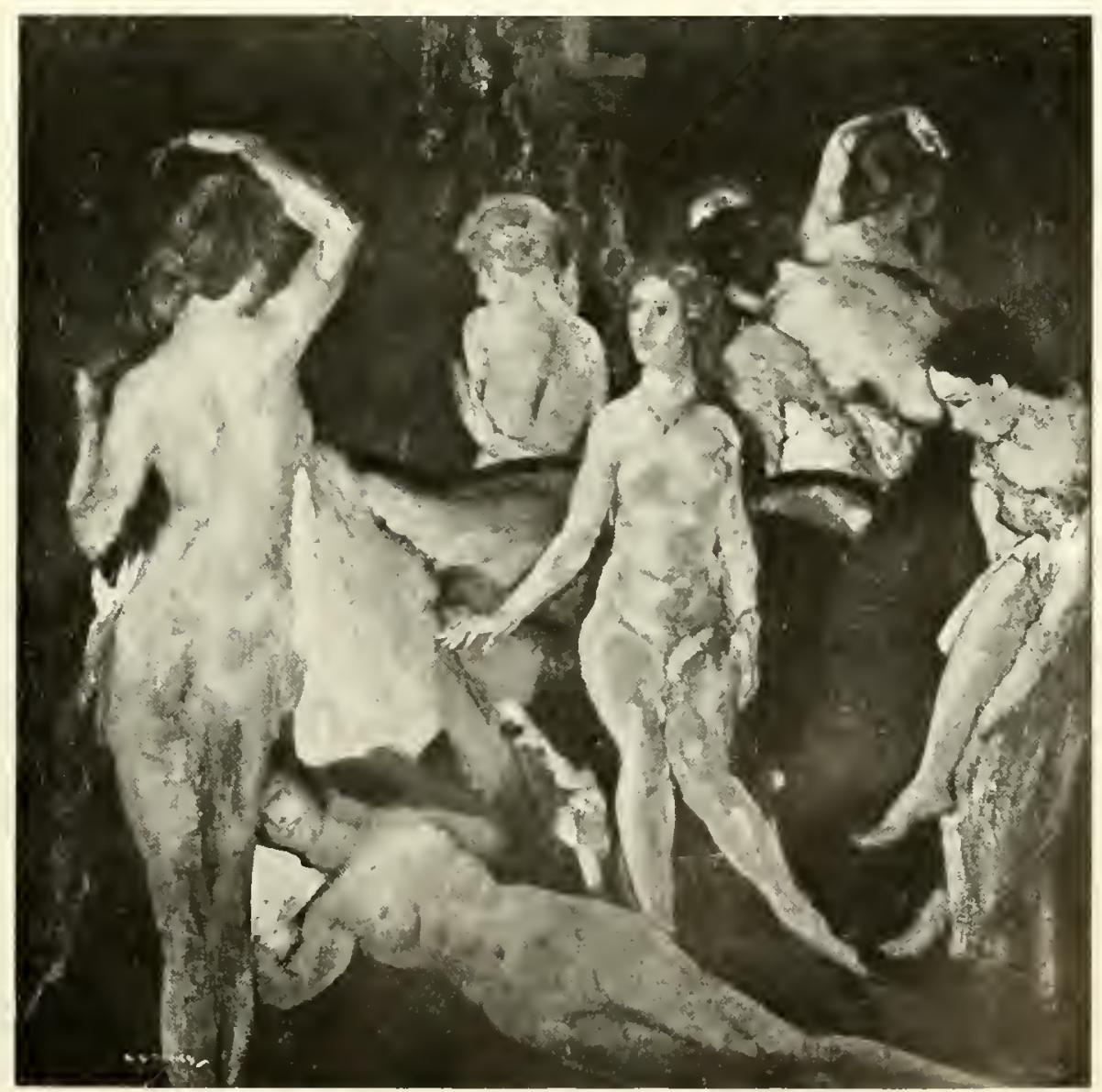



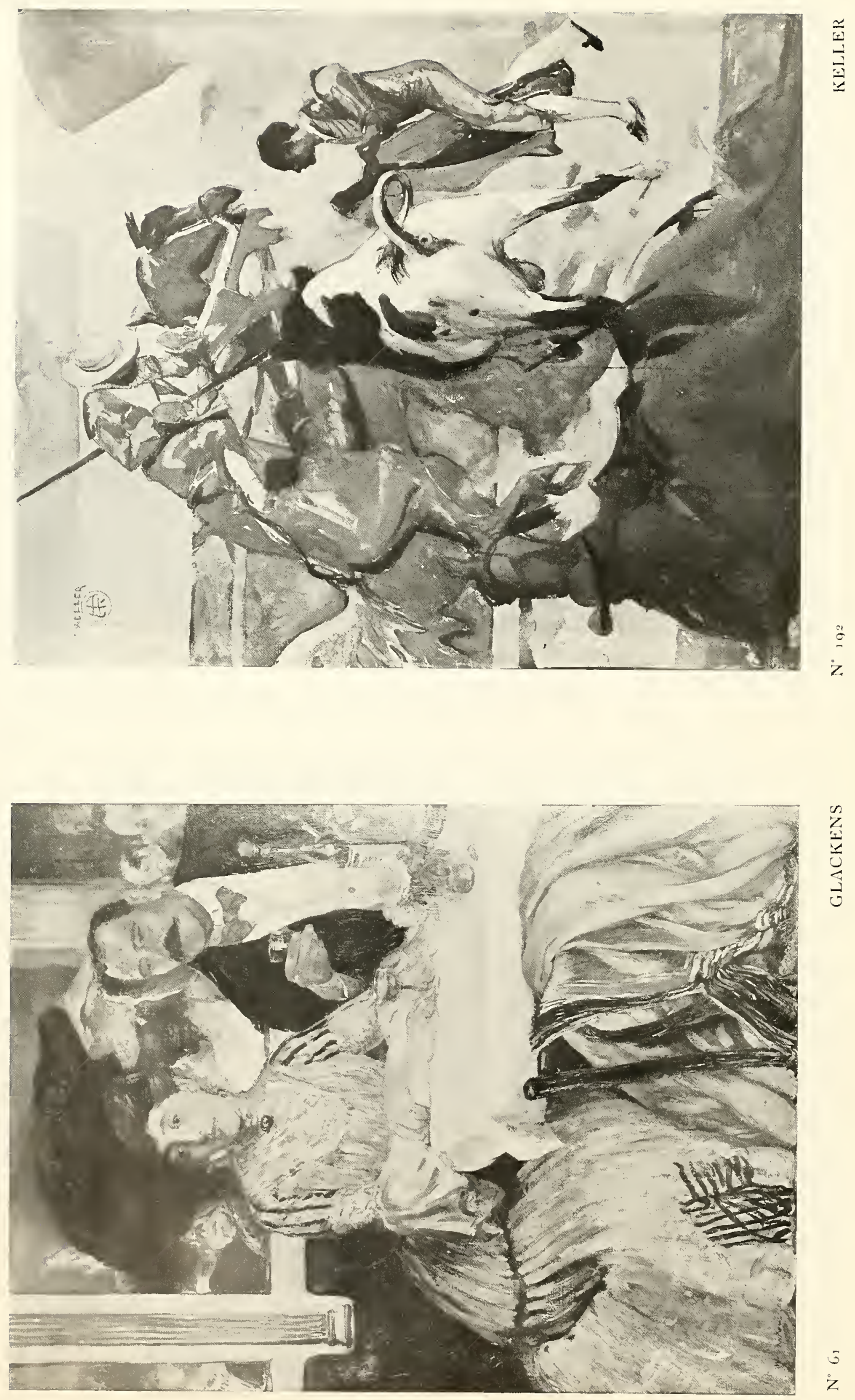

恣 

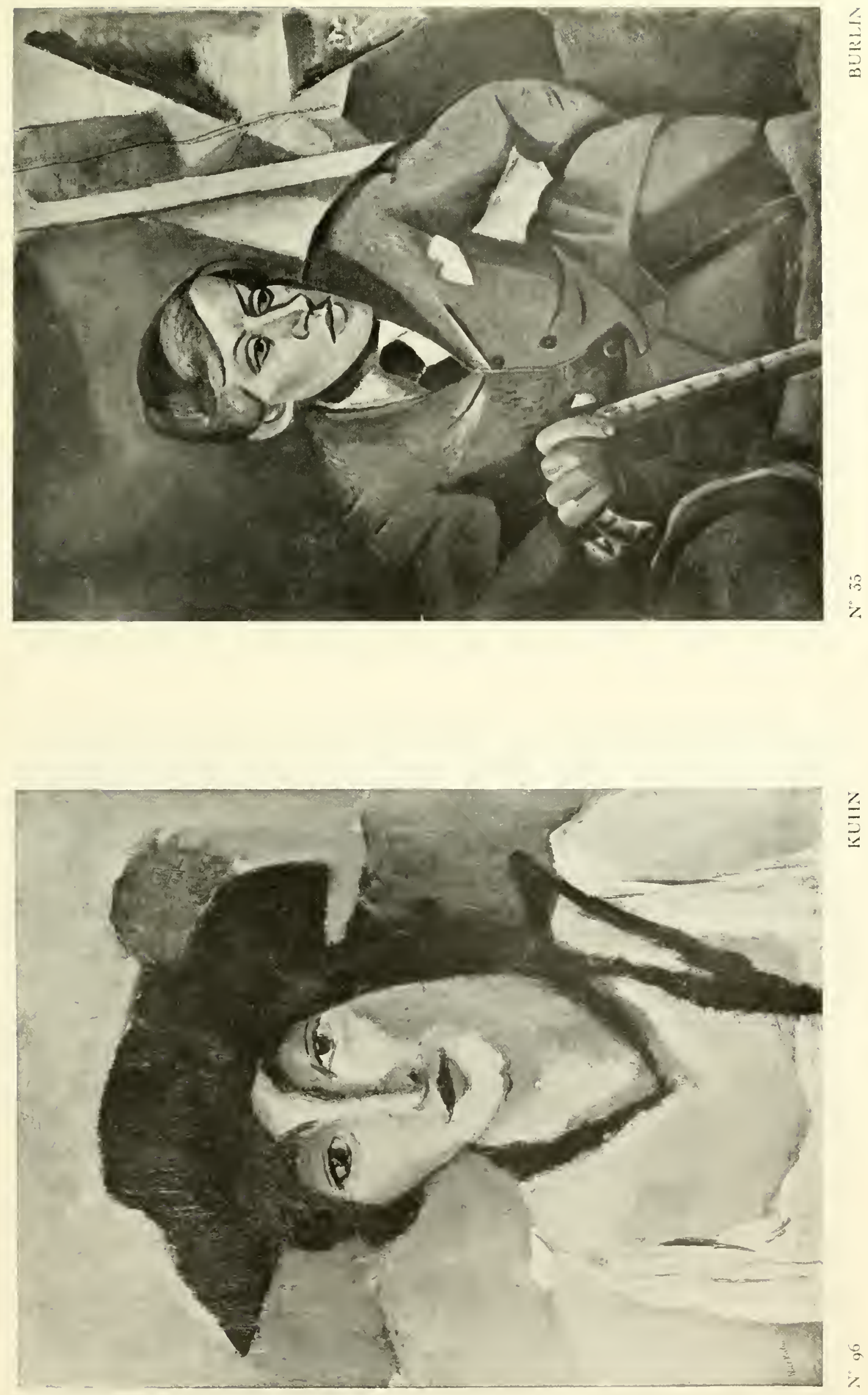

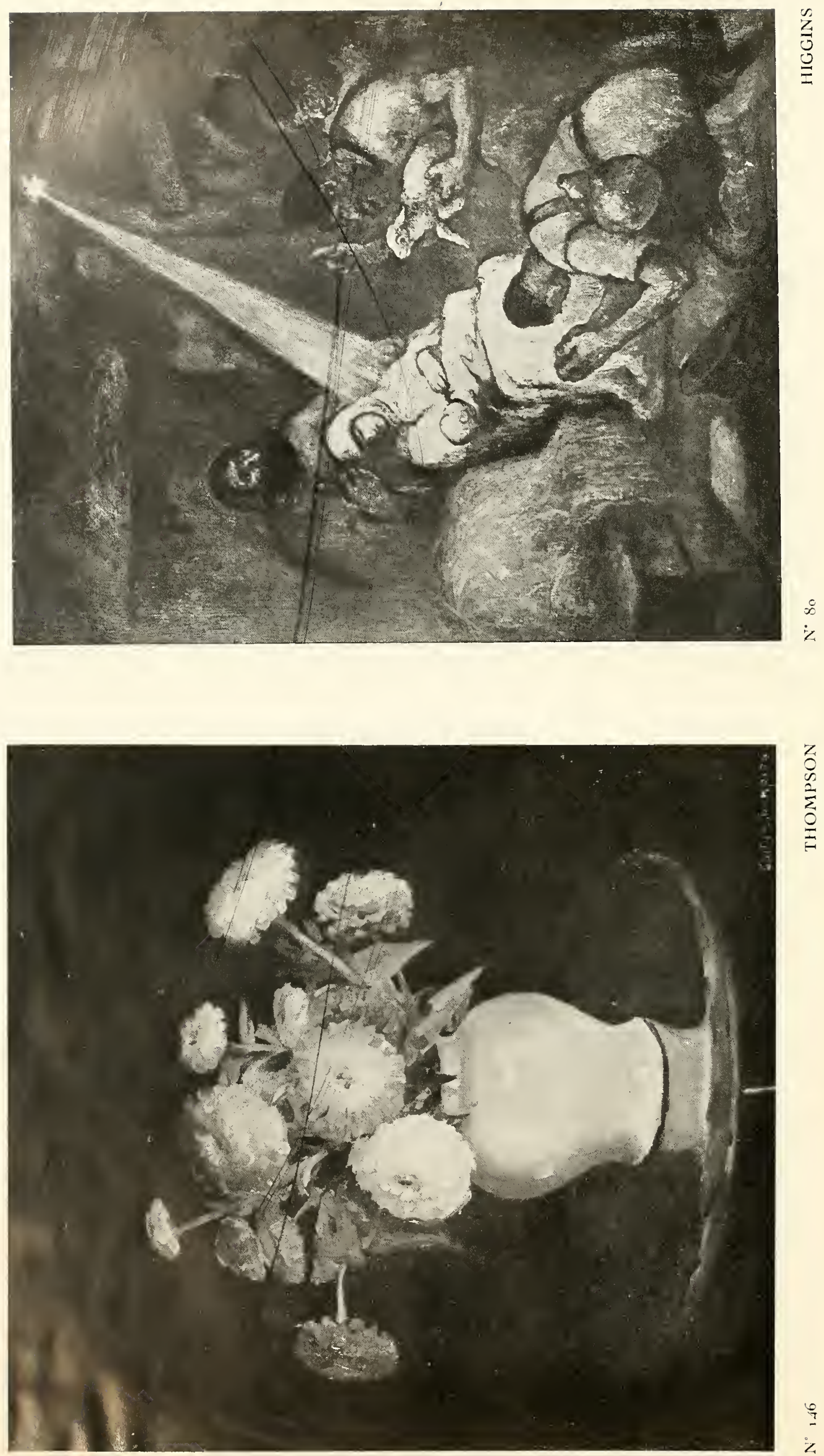

2
0
0
0
$\vdots$
0
1 

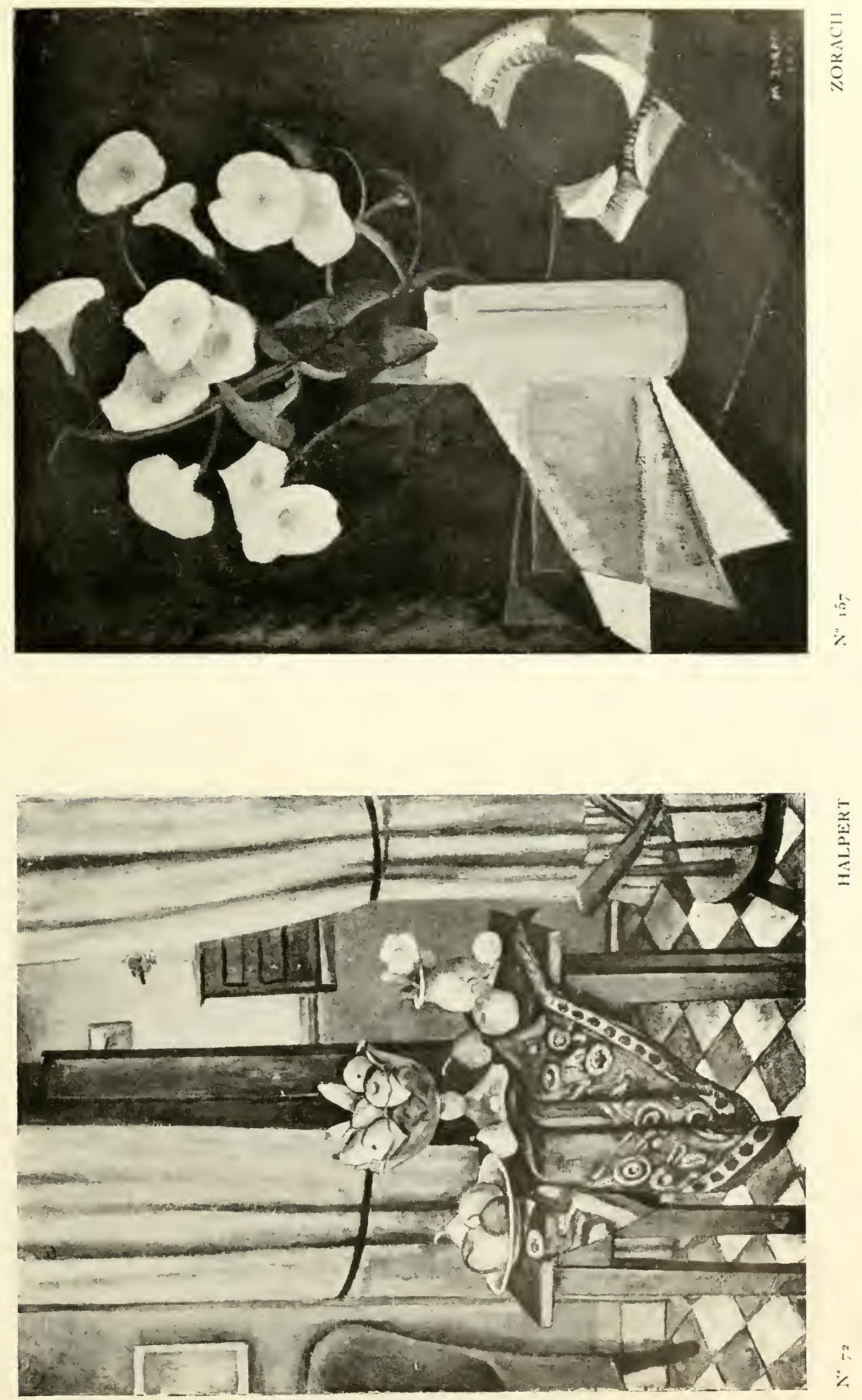

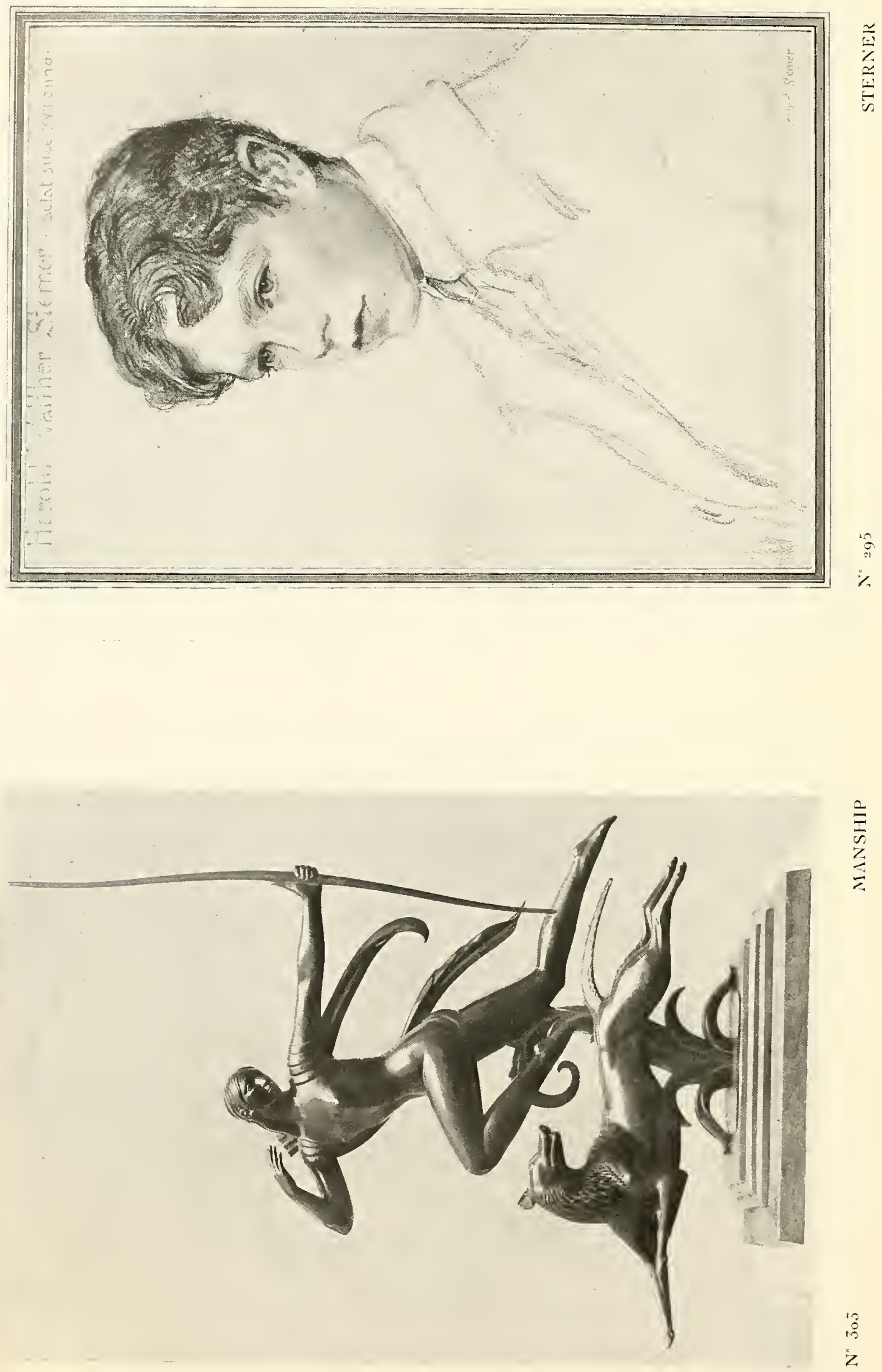
MILLER (Kenneth Hayes) .

$\operatorname{PASCIN}\left(J_{.}\right) . \quad \ldots \quad \ldots \quad \ldots \quad \ldots \quad 12$

POOLE (Abram). . . $\quad \ldots \quad \ldots \quad$ i23 Portrait of Mercedes d'Acosta

124 Crazy House

125 The Back Yard

126 Portrait of $\mathrm{M}^{11 \mathrm{e}}$ Bosnanska

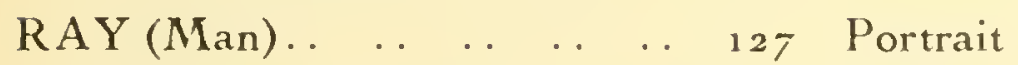

128 Marine

SHORE (Henrietta). . . . . 129 Monhegan Harbor

130 Girl with Fruit

$1 \tilde{3}_{1}$ Life Energes

SMYTH (Marguerite Pumpelly) . . ${ }_{132}$ Portrait of Mrs Zogbaum

133 Portrait of Mrs Belmont

SPEICHER (Eugene) . . . . 134 Portrait of a Dancer

135 Girls Head

136 Portrait of a French Girl

SPRINCHORN (Carl) . . . $\quad{ }_{137}$ Boreal Forest Pageant

138 Autumn Still Life

STERNER (Albert).. .. . . ,39 The Bath

140 The Japanese Print

141 In Fancy Dress

$14:$ Portrait of Mrs Sterner

143 The Convalescent

THOMPSON (Edith Blight).. 144 Interior chez la marquise de Polignac

145 Mon Atelier

146 The Green Vase

$14 T$ Flowers and Fruit

Information reyarding condition of wales at special discount and free divivery of piclures to any part of - Europe or tbe United Stated may be bad by inquiring at the Desk. 


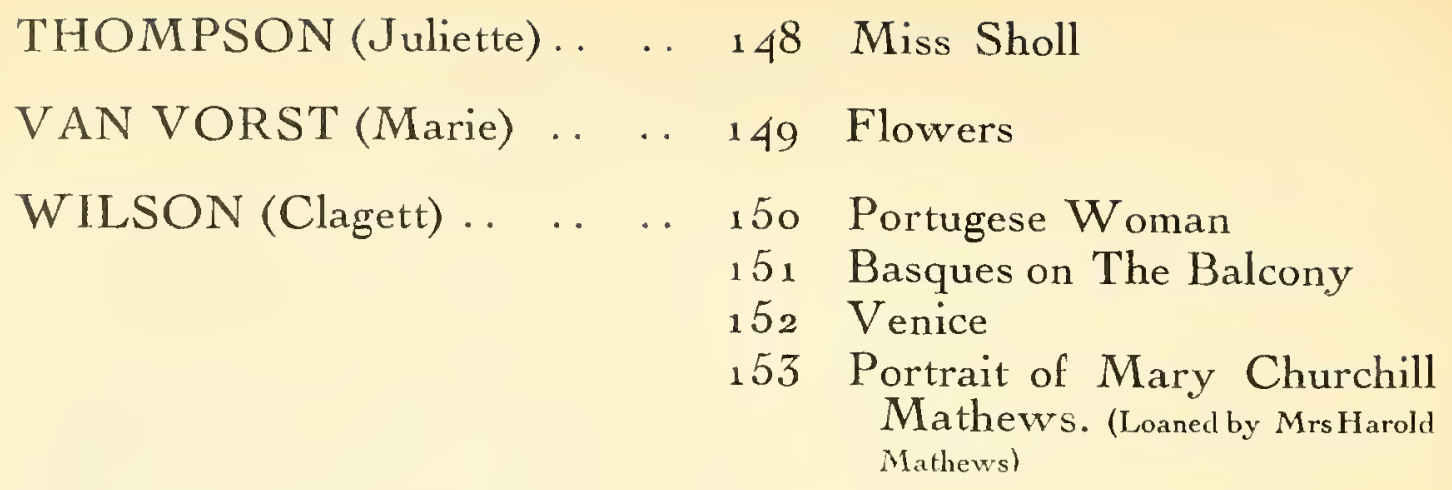

ZORACH (Margueritz) .. . . 154 Mother and Children

155 Child and Blocks

156 Woman, Child and Dog

157 Petunias

158 Lilies of The Valley

ZORACH (William).

160 The Sisters

${ }_{161}$ The Sea

${ }_{1} 6_{2}$ Waterfall

\section{WATER COLOURS}

BELLOWS (George). . . . . 163 The Well

BIDDLE (George) . . . . . . 164 Two Heads

165 Still Life

BRADLEY (Susan).. . . . . $\quad{ }_{1} 66$ The Sphinx

BURCHFIELD (Charles) . . ${ }_{16} 67$ Mining Village

${ }_{168}$ Beginning Snow Storm

169 Over the Village

170 House of Death

171 Watering Time

172 Spring Bonfire

${ }_{173}$ Mining Village in Storm

174 After the Ice Storm

Infornation regarding condition of dales at special discount and free delivery of pictures to any part of Europe or the United States may be bad hy inquiring at the desk. 


\begin{tabular}{|c|c|c|c|c|}
\hline BURCHFIELD (Charle & & & $\begin{array}{l}175 \\
176 \\
177 \\
178 \\
179 \\
180 \\
181 \\
182 \\
183\end{array}$ & $\begin{array}{l}\text { Sun behind the Trees } \\
\text { Factories } \\
\text { Gates Dorvn } \\
\text { Three Trees and Pool } \\
\text { December Twilight } \\
\text { Negley. Ohio } \\
\text { Burning Hillside } \\
\text { Eating Place } \\
\text { February Dusk }\end{array}$ \\
\hline BURLIN (Paul). . & . & 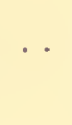 & $\begin{array}{l}184 \\
185\end{array}$ & $\begin{array}{l}\text { Tunis } \\
\text { Tyrol }\end{array}$ \\
\hline DAVIS (Stuart) .. .. & . & . & $\begin{array}{l}186 \\
187\end{array}$ & $\begin{array}{l}\text { Babe-la-Tours } \\
\text { Vaudeville }\end{array}$ \\
\hline HALE (Gardner). & . & . & $\begin{array}{l}188 \\
189\end{array}$ & $\begin{array}{l}\text { Roofs in Italy } \\
\text { Bare Trees }\end{array}$ \\
\hline HART (George) "Pop" & . . & . & $\begin{array}{l}190 \\
191\end{array}$ & $\begin{array}{l}\text { Market Boats } \\
\text { Boats in Harbour }\end{array}$ \\
\hline $\operatorname{KELLER}($ H. G.) . . & . & . & ${ }^{192}$ & Bull Fight \\
\hline KUHN (Walt) . . . & $\cdots$ & . & 193 & The Country Road \\
\hline MATULKA (Jan) . & . & . & $\begin{array}{l}194 \\
195 \\
196 \\
197\end{array}$ & $\begin{array}{l}\text { Netherlands Hotel } \\
\text { Bridge } \\
\text { Indian Dance } \\
\text { Landscape }\end{array}$ \\
\hline NIVISON (Josephine) & . & $\cdots$ & $\begin{array}{l}198 \\
199 \\
200\end{array}$ & $\begin{array}{l}\text { Petunias } \\
\text { Larkspur } \\
\text { The Picnic }\end{array}$ \\
\hline $\operatorname{PASCIN}\left(J_{.}\right) . \quad \ldots \quad \ldots$ & . & . & $\begin{array}{l}201 \\
202\end{array}$ & $\begin{array}{l}\text { Watercolor } \\
\text { Watercolor }\end{array}$ \\
\hline ROBERTS (John) . . & $\cdots$ & $\cdots$ & 203 & Walt Whitman \\
\hline SPRINCHORN (Carl) & . & & 204 & Dancer \\
\hline
\end{tabular}

Information regarding condition of sales at sopcial discount and free delivery of pictures to any oart of Europe or the United States may be bad by inquiring at the desk. 


\begin{tabular}{|c|c|c|c|c|}
\hline STERNE (Maurice) & . & . & 205 & Mother and Child (Pastel) \\
\hline & & & 206 & Under the Tree \\
\hline STERNER (Harold). . & & & 207 & ge, Saint-James \\
\hline & & & & \\
\hline WALKER (Sybil) & . & 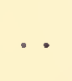 & 209 & New-York Harbour \\
\hline WILSON (Clagett) & $\ldots$ & & 210 & $\begin{array}{l}\text { Moving up for Saint-Mihiel } \\
\text { Fight }\end{array}$ \\
\hline ZORACH (William). & & & $\begin{array}{l}211 \\
212\end{array}$ & $\begin{array}{l}\text { Maine Coast } \\
\text { Adoration }\end{array}$ \\
\hline
\end{tabular}

\section{DRAWINGS, LITHOGRAPHS, etc.}

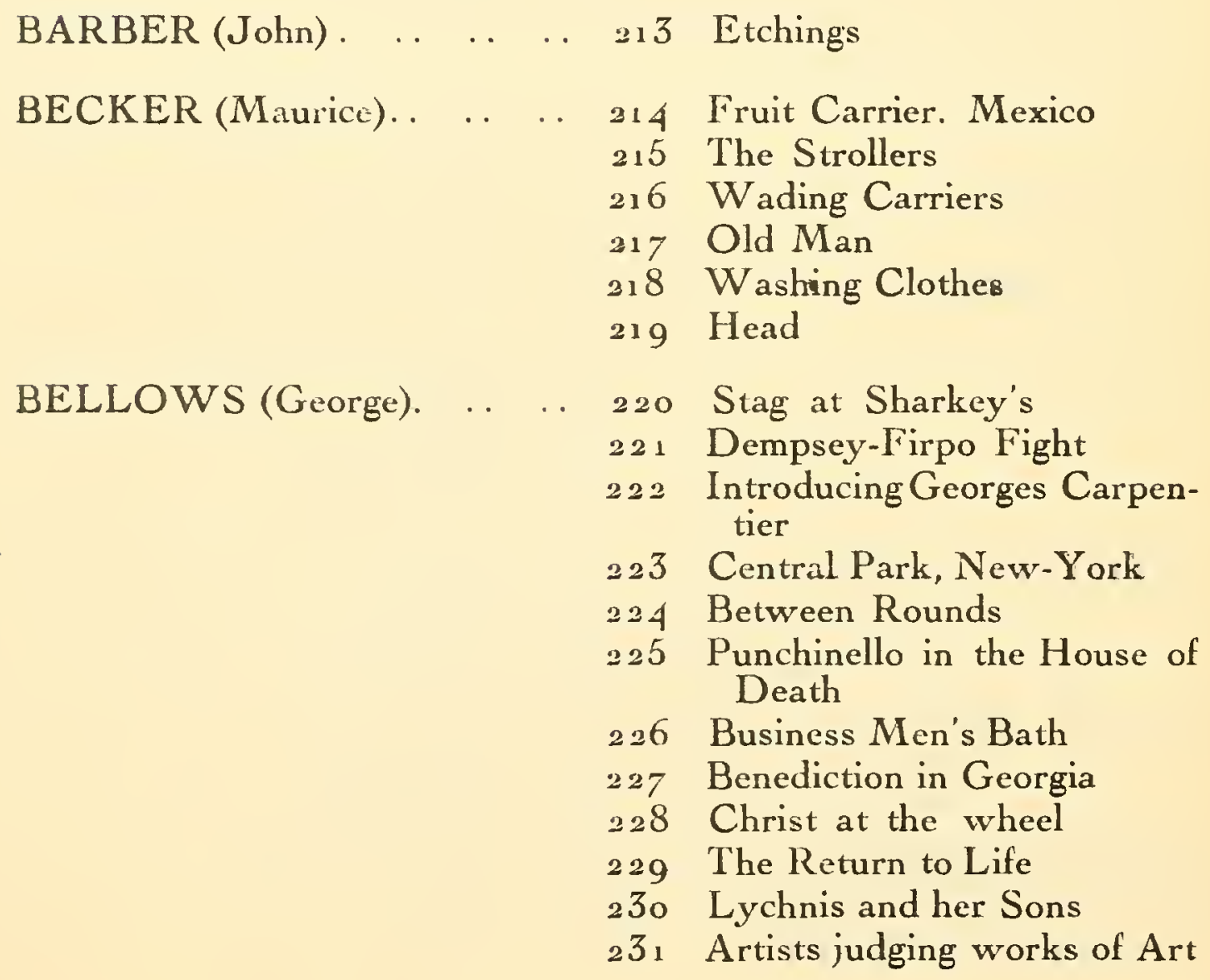




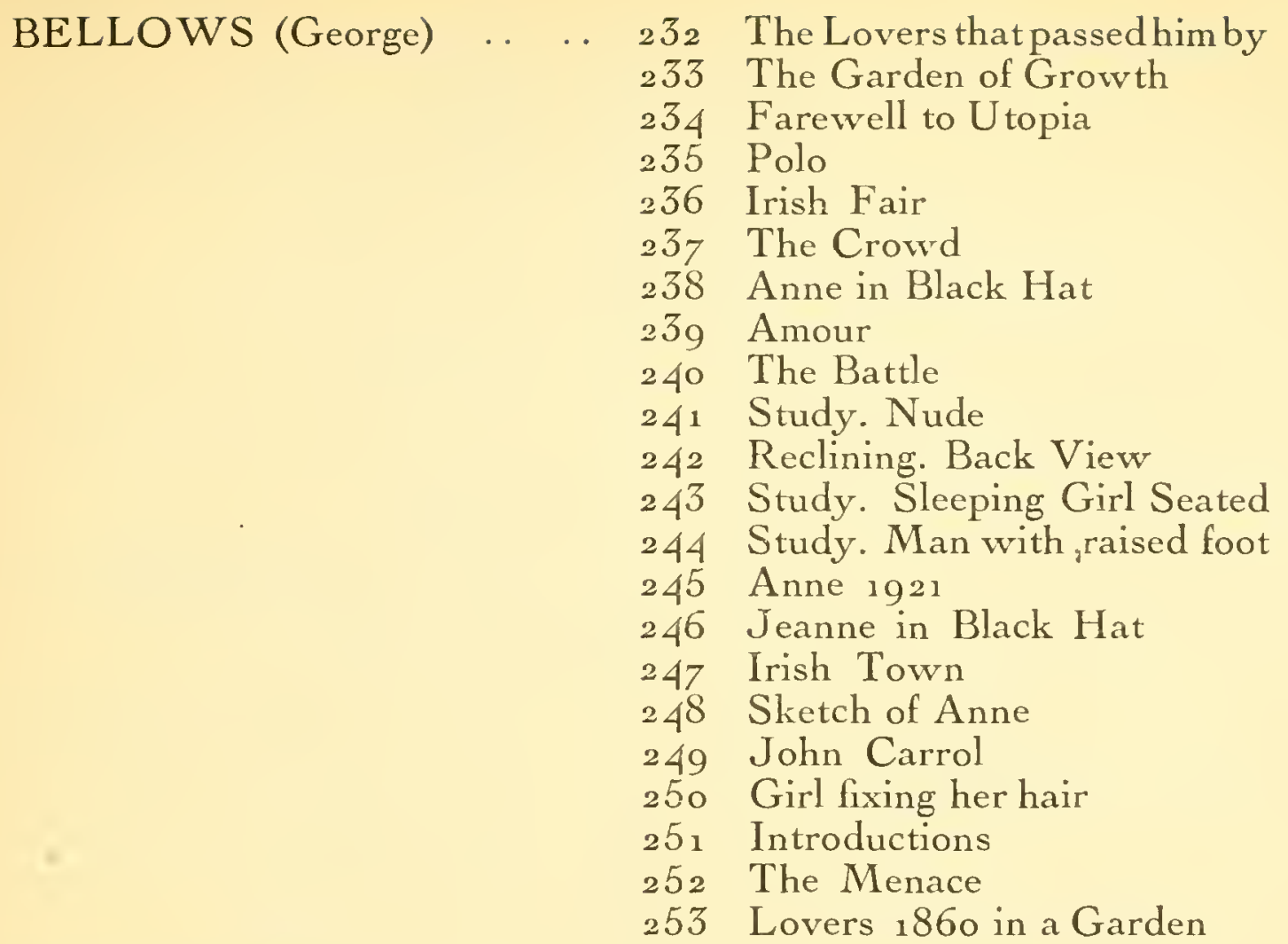

BUCHHOLZ (Frederick). . . 254 Bouquet of Daisies 255 Flowers in a Glass

BURLIN (Paul). . $\quad . \quad \ldots \quad \ldots \quad 256$ Africans (a) 257 Africans (b)

DAVIES (Arthur B.). . . . $\quad{ }_{2} 58$ Lithograph

HART (George Pop).. . . . . 259 A jug and a loaf of bread and thou

26o Cock-fight

261 Natives washing clothes. Santa Domingo

202 Natives witx Market Boats

${ }_{2} 63$ Market

KENT (Rockwell) . . . . . $\quad 264$ The Snow Queen

${ }_{265}$ Man

${ }_{266}$ Woman and Child

Information regarding condition of sales at spucial discount and free delivery of pictures to any part of Europe or the United States may be bad by inquiring at the desk. 


\begin{tabular}{|c|c|c|}
\hline UHN (Walt) & $\begin{array}{l}\ldots \quad 267 \\
268 \\
269 \\
270\end{array}$ & $\begin{array}{l}\text { Mask } \\
\text { Frontier People } \\
\text { Model } \\
\text { Horse thieves }\end{array}$ \\
\hline MATULKA (Jan) .. & 271 & Group Figures \\
\hline $\operatorname{PASCIN}\left(\mathrm{J}_{0}\right)$ & $\begin{array}{l}272 \\
273\end{array}$ & $\begin{array}{l}\text { Drawing } \\
\text { Drawing }\end{array}$ \\
\hline ROBINSON (Boardman). & $\begin{array}{r}274 \\
275 \\
276 \\
277 \\
278 \\
279\end{array}$ & $\begin{array}{l}\text { Suzannah } \\
\text { Portrait } \\
\text { Marianne sees the Gipsy } \\
\text { Study for Decoration } \\
\text { Lord Curzon } \\
\text { Sidney Webb }\end{array}$ \\
\hline STERNER (Albert).. & $\begin{array}{r}280 \\
281 \\
282 \\
283 \\
284 \\
285 \\
\\
286 \\
287 \\
288 \\
289 \\
290 \\
291 \\
\\
292 \\
293 \\
294 \\
295 \\
296\end{array}$ & $\begin{array}{l}\text { Amour Mort } \\
\text { (Loaned by major A. Simson). } \\
\text { Olivia seated } \\
\text { Kiss of an Angel } \\
\text { The Stranger } \\
\text { The Black Angel } \\
\text { The Fall of the House of } \\
\text { Usher (Poe) } \\
\text { The Burden } \\
\text { Douleur } \\
\text { The Black Cat (Poe) } \\
\text { Negro } \\
\text { Homeless } \\
\text { Portrait of } \quad M^{r} \quad \text { Edmond } \\
\quad \text { Quinn } \\
\text { Portrait of } M^{\text {rs }} \text { Gwendolen } \\
\text { Portrait of } M^{r} \text { Oovil Toole } \\
\quad-\quad M^{\text {rs }} \text { Locher } \\
\quad-\quad M^{r} \text { Harold Sterner } \\
-\quad M^{r} \text { Oakes Ames }\end{array}$ \\
\hline
\end{tabular}




\section{SCULPTURE}

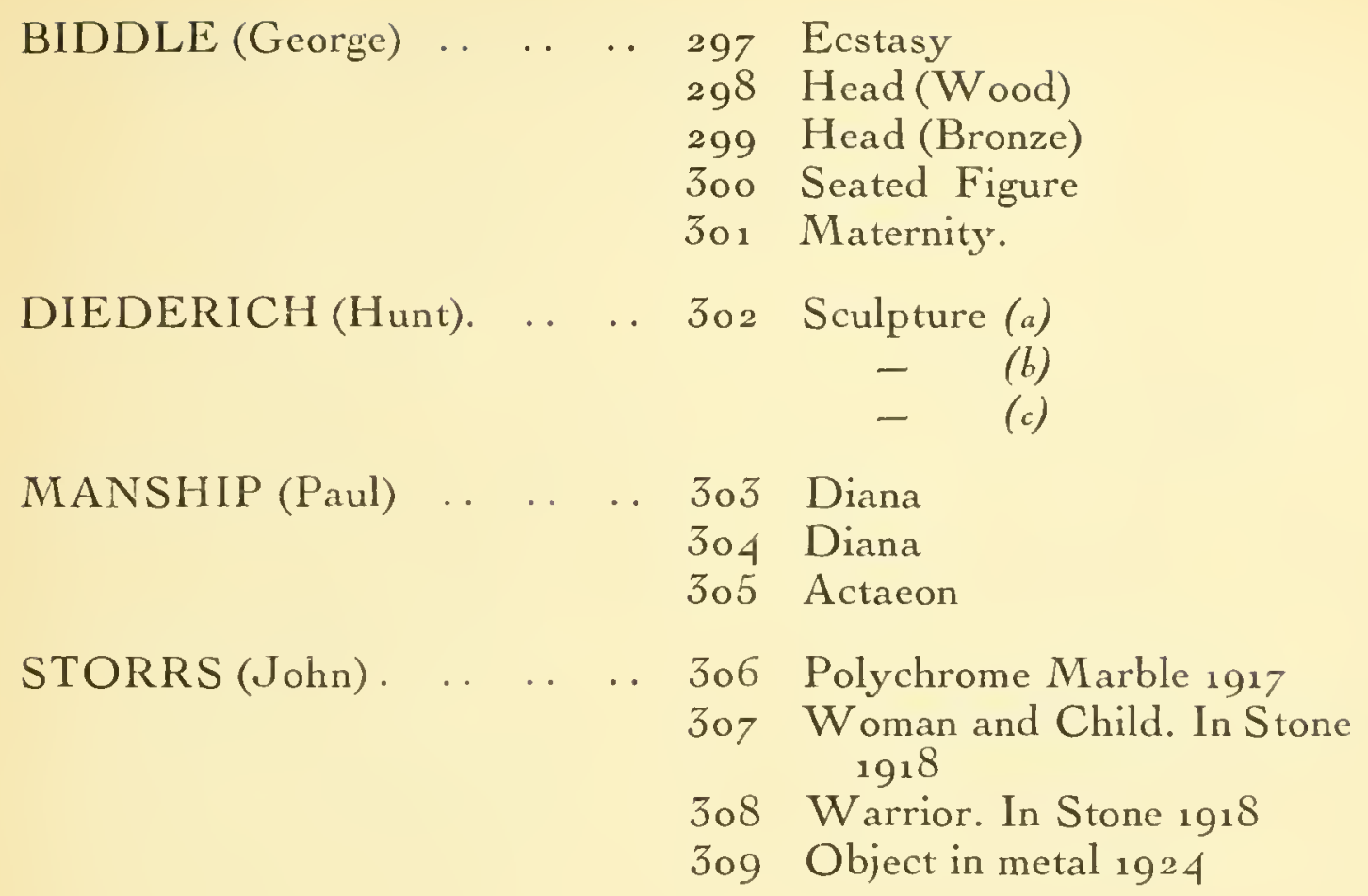

Information regarding condition of sules at special discount and free delivery of pictures to any part of Europe or the United States may be bad by inquiring at the desk. 


\section{THE NEW GALLERY, INC.}

\section{NEW-YORK}

6oo, Madison Avenue, 6oo

Modern American and European Paintings

CHAPIN, FIENE,

WHEELOCK, STELLA, SPRINCHORN, HARTLEY, PASCIN

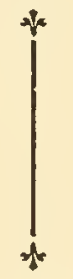

GRIGORIEV, MATISSE, DERAIN, VLAMINCK, UTRILLO, MODIGLIANI, DUFY.

\section{DAVIES, TURNER et COCQUYT} (France) S. A.

TRANSPORTS INTERNATIONAUX, AGENCE EN DOUANE

Assurances - Camionnage

Magasinage - Déménagements - Commissions

23, Rue Baudin, PARIS (IX ${ }^{e}$

52, Lime Street, LONDON E.C. 3

39, Pearl Street, NEW-YORK

Agents dans les principaux ports du Monde Maison Fondée en 1870 


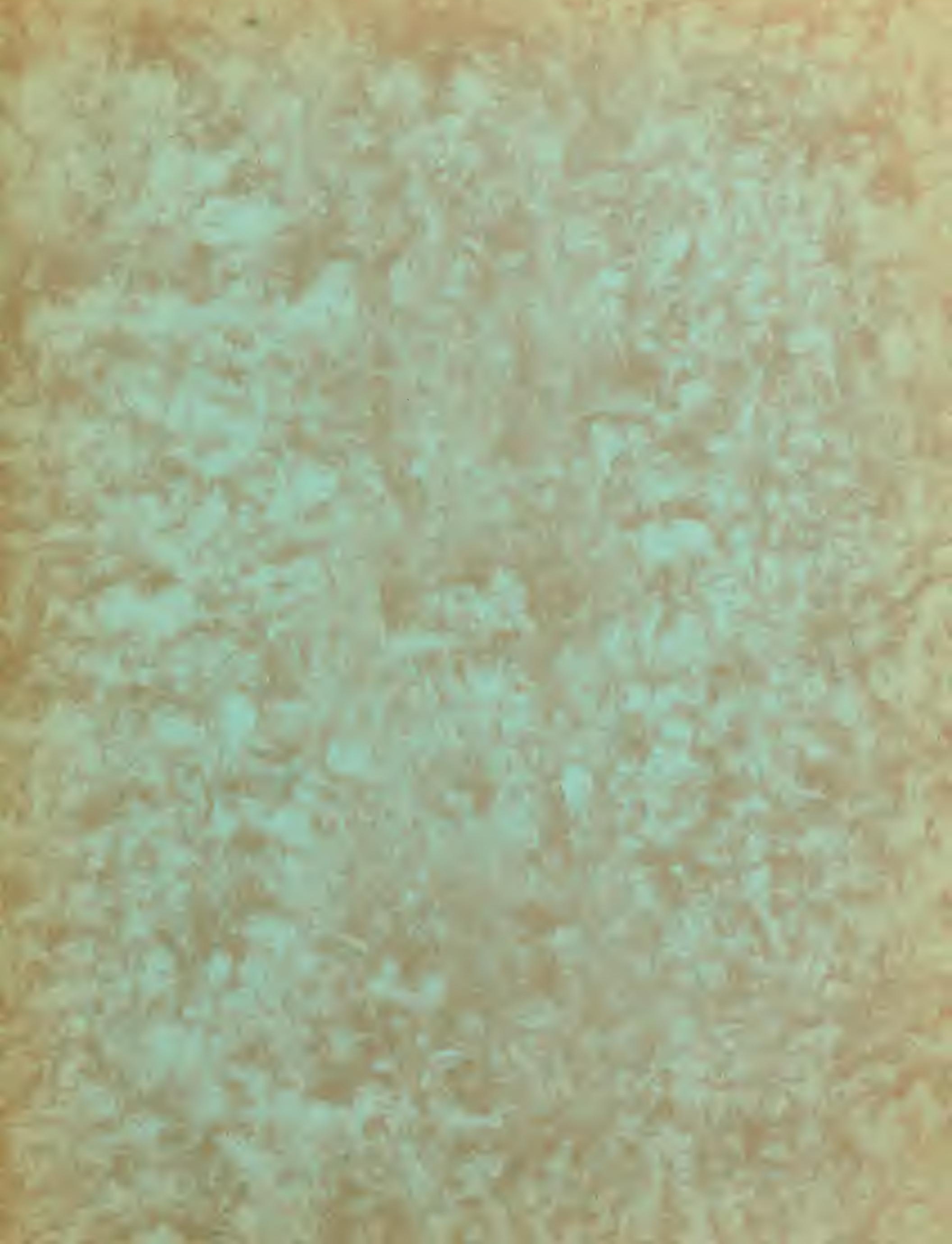




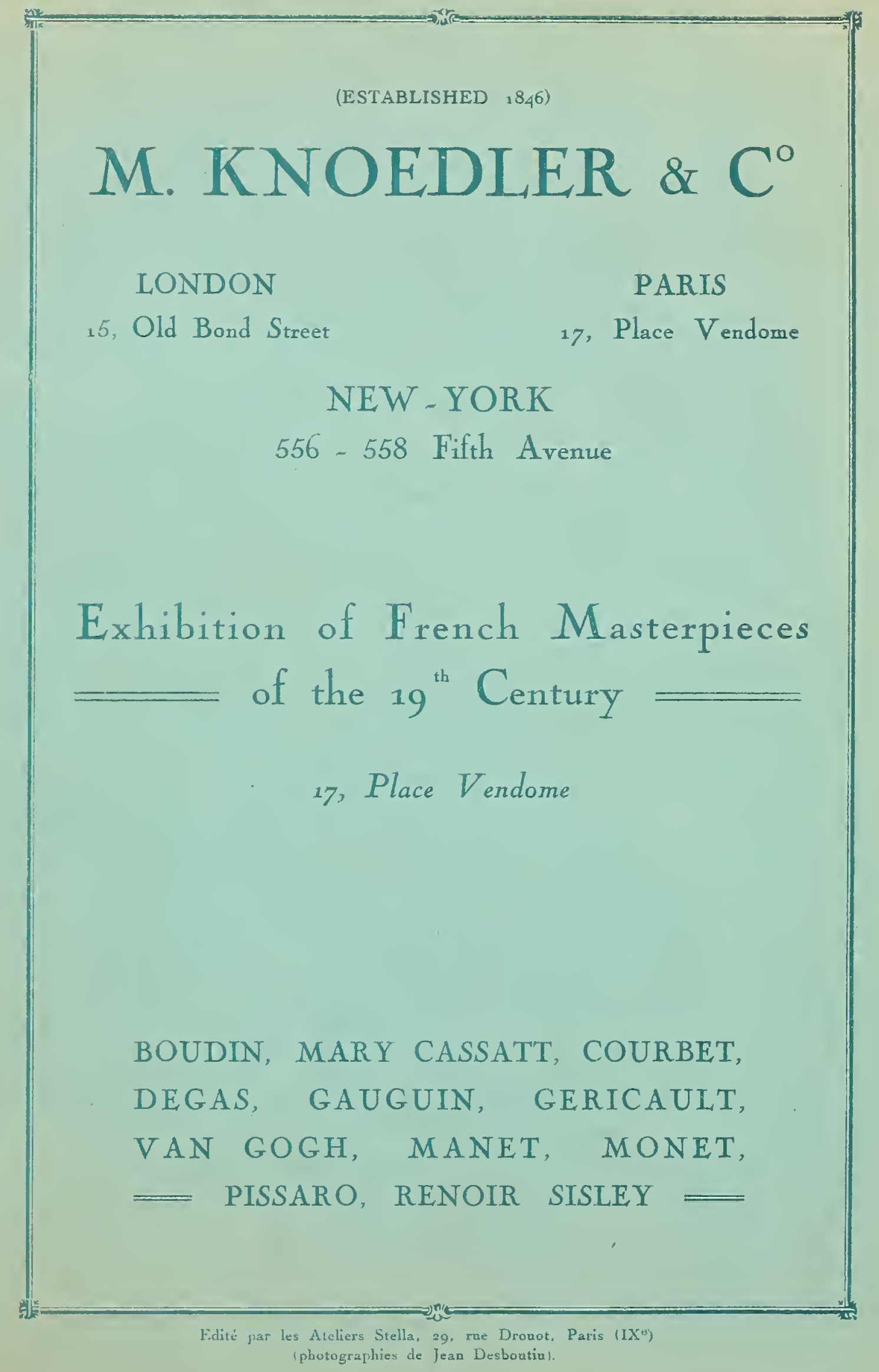




